Article

\title{
Addressing Uncertainty of Environmental Governance in Environmentally Sensitive Areas in Developing Countries: A Precise-Strike and Spatial-Targeting Adaptive Governance Framework
}

\author{
Xiaohui Ding ${ }^{1, *(\mathbb{D}}$, Chen Zhou ${ }^{2}{ }^{\mathbb{D}}$, Weizhou Zhong ${ }^{3}$ and Pingping Tang ${ }^{4}$ \\ 1 Northwest Institute of Historical Environmental and Socio-Economic Development, \\ Shaanxi Normal University, No. 620, West Chang'an Avenue, Xi'an 710119, China \\ 2 School of Economics and Statistics, Guangzhou University, No. 230, Huanxi Road, Guangzhou 510006, China \\ 3 School of Finance and Economics, Xi'an Jiaotong University, 74, Yantaxi Road, Xi'an 710063, China \\ 4 Southern Shaanxi Center for Green Development and Ecological Compensation Research, \\ Shaanxi University of Technology, Hanzhong 723001, China \\ * Correspondence: xhding@snnu.edu.cn; Tel.: +86-029-85318752
}

Received: 29 June 2019; Accepted: 16 August 2019; Published: 20 August 2019

check for updates

\begin{abstract}
Endowed with distinctive natural ecosystems and abundant biodiversity, regional environmental governance in developing countries, especially the environmentally sensitive areas (ESAs), is facing the daunting task to ultimately divert their regional development mode towards sustainable fashion through governance transition. However, given their less-developed status in particular expressed by under-developed economies, unsound political regimes, low governance capacity, such task seemingly insurmountable. In order to approach the incompatibility between economic development and maintenance of the ecosystem services value, and understand the complex and interlocked nature of the regional institution system of ESAs in developing countries, an ecosystem services value-based adaptive governance model was introduced to identify the deficiencies and failures of existing regional environmental governance and establish innovative arenas and transition agendas for innovating and reframing regional institutions and modifying role of regional actor groups and governance mode in the process of decision making on environmental issues. Such approaches were conducted in a circular diverting process in order to facilitate the mode of regional development transforming towards sustainable development. For demonstration the process of application and effectiveness of this methodology, a case study was conducted in a typical ESAs-the Water Source Area of the Middle Route Project of the South-North Water Diversion Project in China. Through integrating the ecosystem services value (ESV) assessment into a wider framework of institutional change, the regional institution system innovation and reformation was directed by taking the ESV changes and pattern of its geo-distribution in the research area as indicators or clues. Compared with traditional proposals for administrative change, the methodology proposed in this study was not prescriptive or directive: Rather, an approach for influencing the direction and speed of transition through a series of steering and coordination mechanism. Therefore, this model is with the potential to be implemented by local communities in regions, especially ESAs in developing countries, to encounter with similar regional development challenges and complex, interlocking, and over-dated regional institutional system associated with environmental issues.
\end{abstract}

Keywords: environmentally sensitive area (ESA); Middle-Route Project (MRP) of the South-North Water Diversion Project (SNWDP); sustainable development; uncertainty of environmental governance; environmental equity 


\section{Introduction}

Regions in developing countries endowed with distinctive natural ecosystems and abundant biodiversity are often classified as environmentally sensitive areas (ESAs) by regional or national authorities [1,2]. Despite these semantic efforts, such regions commonly face a 'regional development dilemma', and the local governments in these regions are burdened with contradictory mandates: On one hand, they are expected to maintain the functionality and integrity of their ecosystems (both locally and as part of the wider ecosystems), yet, on the other hand, they are expected to revitalize the local economy and augment the social and material wellbeing of the local communities.

Such a dilemma is intimately related to not only their development level-such regions often have under-developed economies, unsound political regimes, and low governance capacity [3,4] —but also development modes, e.g., in such regions economic development is often synonymous with rapid urbanization [5]. Propelled by the rapid economic development that has characterized developing countries for the last three decades [6], this massive urbanization process has caused tremendous problems in these regions in terms of the environment as well as other issues (e.g., public health, quality of life, international industrial competition, and social cohesion and stability) [7]. The resilience of these regions' socio-ecological systems is threatened, and their current development trajectories are compromising their potential for a sustainable future.

The environment is important for people in developing economies due to their vulnerability, high dependence on natural resources and low capability to cope with external shocks (e.g., floods and droughts) [8]. As acknowledged by a number of multilateral environmental agreements (MEAs) under the UN-system, good environmental governance is crucial for human development, poverty reduction, and long-term economic growth, and can further contribute to improve gender equality as well as sustainable development. However, although the basic legal and policy frameworks are often in place in developing and transitional countries, the major challenge is the implementation gap, which is particularly evident at the sub-national level [9], denoting the ineffective implementation of existing frameworks [10]. In addition to traditionally identified factors that led to this implementation gap in developing countries, which is explained by a lack of technical and financial capacities among young environmental agencies in combination with the low political priority given to environmental aspects [11], the importance of environmental governance is increasingly emphasized [12,13].

Environmental governance, which refers to the set of regulatory processes and organization through which political actors influence environmental action and outcomes [14], is varied in form, critical in importance, and near ubiquitous in spread [15]. The focus of environmental governance has evolved, from advocating for effective environmental management by viewing communities and local institutions as important actors in the process of governance in the 1980s and early 1990s to a new form of environmental governance that relayed more on partnerships since the mid-1990s, denoted as co-governance, public-private partnership, and social-private partnership [16]. Contemporary studies on environmental governance have highlighted several key ideas as follows: Addressing the novel and innovative institutions, institutional arrangements and incentives facilitating collective action [17-19], crucial role of non-state actors in regional environmental governance [19-21], cross-scale issues in governance $[17,18,22,23]$, and adaptive manner of environmental governance in the context of environmental challenges (e.g., complex adaptive and social-ecological systems) $[24,25]$.

However, much less attention has been paid to the analytical framework for addressing the uncertainties in environmental governance that cause challenges in governing cross-regional environmental issues in developing countries. Additionally, previous studies have neglected the methodological framework for diverting regional environmental governance transition towards sustainability in the context of the developing world. Consequently, the aim of this study is to provide a more precise-strike and spatial-targeting framework that can be used to pinpoint regions where environmental challenges have emerged and identify the underlying uncertainties that led to such challenges, based on which an adaptive institution transition model can be built for regional institution innovation and reformation. 
Ecosystems can provide multiple ecosystem services, whether tangible or intangible, to a local community as well as in regions at wider scales [26]. In this research, variation in the ecosystem services value (ESV) in the Water Source Area (WSA) of the Middle Route Project (MRP) of the South-North Water Diversion Project (SNWDP) in China (abbreviated as WSA of MRP or 'research area'), as a typical ESA in developing countries, was taken as the research object. The research area, as characterized by its abundant water resources and high-quality natural environment, is of high value in terms of environmental protection and ecosystem conservation. After a total investment of USD 33 billion and 14 years of construction of the MRP of the SNWDP, the top priority for environmental governance in the research area is to maintain the high quantity and quality of water diverted from this region, through strategies and procedures, in a short-term perspective, to maintain the quantity and quality of ecosystems in the research area, while in the long run, to facilitate regional development mode transformation towards sustainability. Since most regions in the research area were selected as the National Ecological Civilization Experimental Zone by the central government and under substantial institutional innovation and reformation process regarding their 'ecological civilization system', these regions are of great potential to become a pilot zone for environmental governance advancement in the context of developing economies.

The rest of this paper was organized as follows. Section 2 started by developing and providing detailed narratives of the theoretical framework-an ecosystem service value (ESV) based adaptive governance model (AGM) for diverting regional environmental governance transformation. Then, the research area and methodology used in this research were introduced in Section 3. Section 4 reported the main findings of this research, and these findings were discussed in Section 5. Finally, Section 6 concluded this research.

\section{Ecosystem Service Value (ESV) Based Adaptive Governance Model (AGM) for Regional Institutional Innovation and Reframing}

\subsection{Uncertainty in Environmental Governance}

As being increasingly characterized by social-ecological complexity [27], uncertainty in environmental governance issues has attracted considerable scholarly attention from the fields of environmental science and environmental governance [28]. Such studies have been conducted in relation to, for example, climate change [29-32], forestry [33,34], and water resources [35-38], and some of these studies have subsequently called for more robust and flexible policy alternatives [39,40].

The causes of uncertainty in environmental governance stem from a lack of awareness of environmental issues and the complex environmental governance contexts. For the former factor, environmental issues, as noted by United Nations Environment Programmes (UNEP, 2006, p. 26) [41], are 'atmospheric, geological, hydrological, biological, and other earth system processes that are being altered by human activity. The scale, spread, and rate of change of global drivers are without precedent'. Although many multi-dimensional approaches used to curb environmental destruction have been elaborated by human beings on the rural, urban, energy, transportation, legislation, scientific and industrial, and governmental levels [42], the ambiguity of the long-term trend prediction impacts of global environmental issues, such as climate change, as well as less accurate and detailed assessments on the effects of regional environmental issues, e.g., the ecosystem value lost in developing countries, are pressing challenges related to promoting environmental awareness at the regional and global levels. Considering the latter factor, governing environmental issues requires the active involvement of public and private actors from a range of different backgrounds and with vested interests in decision-making. Making such decisions is challenging not only due to the technical complexities of environmental impacts and ecosystems, but also due to the social complexity of the network of other actors who have a stake in these decisions, and the complexity of the institutional settings in which these decisions are made [43].

For a more comprehensive understanding and a thorough address of the uncertainties in the decision-making processes of environmental issues, the framework that is used can benefit from both 
covering a more broad range of social and behavioral uncertainties by including substantive, strategic and institutional uncertainties, and distinguishing between ambiguity, ontological and epistemic uncertainty, which are forms with fundamentally different characteristics [44].

\subsection{From Governance to Adaptive Governance}

Concerns on the sustainability of regional development in developing countries, compared with that in developed countries, are focused on both improving environmental quantity and social equity and reducing poverty [45]. From the former perspective, sustainable development is seen as an issue of development within the ecological boundaries and carrying capacity of the planet, whereby it can be measured and based on scientific evidence. For the latter perspective, the welfare of sustainable development conceptualizes sustainable development as a quality of life issue (in an intertemporal sense) rather than an environmental issue. As the concept of welfare used to define the minimal quality of life for the population around the world, and recognizing the scarcity and vulnerability of natural resources, the point of sustainable development is to improve the life of people at the global level, maintaining the environmental capability of securing both inter-and intra-generational stability of welfare [46]. In other words, regions in developing economies should divert their development pattern towards a global framework of environmental justice for all, based on the idea of a fair use of natural resources [47].

In recent years, a number of countries have begun to address a phenomenon known as 'environmental injustice', which represents the observation that members of ethnic minorities, communities of lower socio-economic status, the least educated and otherwise marginalized segments society disproportionately: (1) suffer from exposure to environmental hazards due to their proximity to hazards waste sites, incinerator, and other sources of pollution, and/or (2) are denied environmental benefits such as water, sewage treatment facilities, sanitation and access to natural resources [48]. Whereby, in addition to already famous definition of sustainable development, the World Commission on Environment and Development issued in 1987 (known also as the Brundtland Commission) have also stressed that 'inequality is the planet's main environmental problem [49].'

As a main countermeasure coping with 'environmental inequality', the notion of 'environmental justice' was emerged as a public concern as early as 1820 [50], and really born in the United States at the end of the 1970s [51]. Thereafter, a substantial body of literatures documents findings on the environmental inequality with broad topics ranging from public health implication of communities residing in polluted neighborhoods [52-54] to global environmental inequality [55-58] to qualitative examination of environmental justice organizations and environmental justice communities [59-61]. Today, a series of environmental studies, emerged as an interdisciplinary body of literatures, concludes that, in general, ethnic minorities, indigenous persons, people of color, and low-income communities confront a higher burden of environmental exposure from air, water, and soil pollution from industrialization, militarization, and consumer practices [62]. Therefore, initiatives aiming at pursuing sustainable development and achieving environmental justice in regions of developing economies demands government activity to propel social change and redistribution of goods and harms, as well as inducing responsibilities and care for nature and human beings, fixing limits on social behaviors, and leaving rooms for pluralism in which individuals and communities would possibly defining their own projects of life, ideas of happiness and welfare [63].

However, the growing number of failed governance attempts to deliver efficient, reliable, and optimal environmental governance [64] has led to calls for more adaptive governance regimes that are capable of dealing with the inherent complexity and uncertainty in the process of pursuing regional sustainable development, especially for developing countries $[25,64,65]$.

Adaptive governance is a continuous problem-solving process [66] 'by which institutional arrangements and ecological knowledge are tested and revised in a dynamic, ongoing, self-organized process of 'learning by doing' [25]. This approach suggests a fundamental paradigm shift from understanding a single part of an ecological system to control its variables to understanding the 
dynamics of the whole social-ecological system to manage its capacity to absorb change and deal with uncertainty and surprise $[25,64,67-69]$.

Adaptive governance involves knowledge accumulation through a process aimed at ensuring a tight feedback between ecosystem change and decision makers $[70,71]$ in a structured cycle of conceptualizing, doing, monitoring, reflecting, learning, and adapting. Because adaptive governance proponents acknowledge problems of ambivalence regarding goals, uncertainty of knowledge, asymmetric distribution of power, and additional management costs, such proponents emphasize participation, experimentation, and collective learning as key elements of governance $[25,65,68,72]$; this shared view provides a good method for diverting and optimizing regional development towards sustainability in developing countries.

\subsection{Ecosystem Service Value (ESV) Based Adaptive Governance Model (AGM)}

In order to divert regional development mode towards more sustainable pattern, especially ESAs in developing world, a comprehensive framework-ecosystem service value (ESV)-based adaptive governance model (AGM) was developed. It composes four functionally independent while logically interlocked components (Figure 1): (I) Evaluation of the spatial and temporal pattern of ESV changes of various ecosystem types or different ecosystem service functions; (II) actuality analysis of regional environmental governance through the lens of cross-scale policy interaction; (III) addressing the regional governance uncertainty and innovating and reframing targets of regional environmental governance; (IV) institution innovation and reformation through a transition circle.

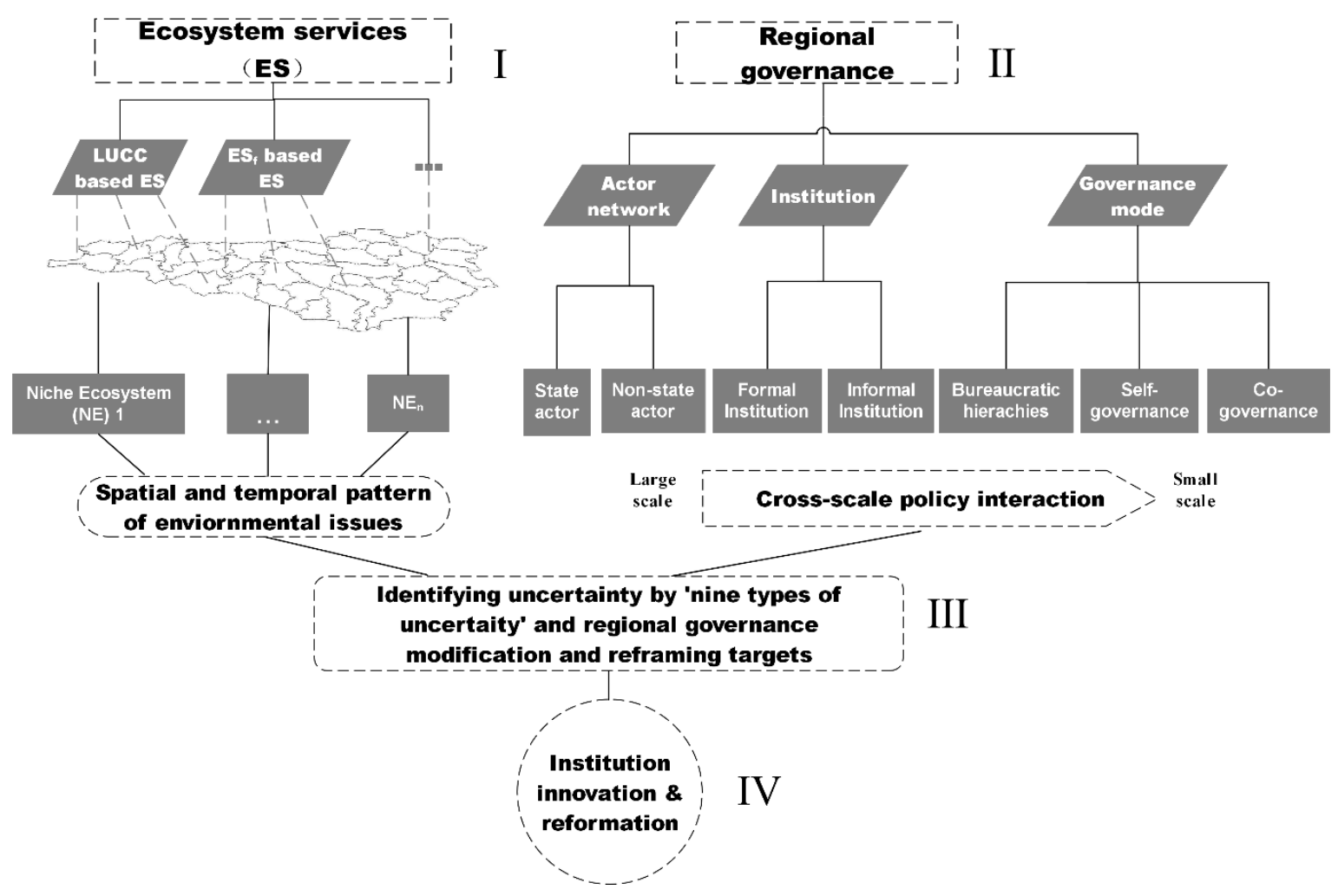

Figure 1. Ecosystem service value (ESV)-based adaptive governance model (AGM) for regional institution innovation and reformation.

\subsubsection{The Spatial and Temporal Pattern of ESV Changes}

To more precisely comprehend the spatial and temporal pattern of ESV changes, the land use and land cover change (LUCC)-based ESV assessment method, from perspectives of both ecosystem types and ecosystem functions, was introduced in this research, and this topic will be detailed later. 
Subsequently, regions where the quality of certain types of ecosystems were increased or degraded and/or regions where certain ecosystem functions were enhanced or weakened in a given period could be identified.

\subsubsection{Actuality Analysis of Regional Environmental Governance}

Regional environmental governance in developing countries, which encompasses the full complexity of regulatory processes and interactions, is treated as a multi-level administration system (Figure 1). It is conceptualized as being composed of three dimensions: institutions, actors, and governance mode.

Institutions are the formal and informal rules and norms that organize social, political and economic relations [73]. Formal institutions include the written constitution, laws, policies, rights, and regulations enforced by official authorities. Informal institutions (usually unwritten) are the social norms, customs or traditions that shape thoughts and behaviors.

As for actors, there are two principal types, namely, state and non-state actors in the context of regional environmental governance in developing countries. The former refers to any type of governmental organization, usually part of a vertical hierarchy that operate within strict jurisdictional boundaries, while the latter refers to private stakeholders, whether economic (e.g., companies, banks) or civil society (e.g., individual, citizen groups). In light of regional environmental governance, the composition of governance actors is often complex [74-77].

Governance mode refers to the extent and nature of involvement by state and/or non-state actors in governing activities [78]. The bureaucratic hierarchies, markets and network are three governance modes corresponding to the three primary modes of social organizations, i.e., the state, market and networks, and represent alternative ways of organizing society [79]. Each institutional arrangement and corresponding governance mode are considered optimal for different economic, social and political circumstances [79].

Needless to say, these straightforward-and somewhat simplified-dimensions of regional environmental governance combine and interact in highly complex ways. While facing certain environmental issues (e.g., urban waterlogging, ecosystem degradation), the nature of regional governance interacting within or across scales is crucial for understanding the scope of actions of agencies and officials at different levels $[80,81]$. Therefore, the actor network theory (ANT), as more focused on social process rather than structure [82], was taken for addressing institutional interaction that accounting for the outcomes of cross-scale environmental governance in the research area.

ANT holds considerable promise of extending our understanding of institutional work [83-85], and therefore, can be taken as tools to better reveal the complexities of our social world. From an ANT perspective, the stable and enduring elements of institution are a 'relational effect' [86] that mask an ongoing and dynamic internal struggle between competing actor-network. One common strategy for revealing the generative intricacies that constitute and stabilize such institutional outcome is to focus on moments of sociotechnical controversy, when networks are interrupted and when their composition become problematic [87]. As for this research, identification of uncertainties in regional environmental governance and formation and initiation of institutional innovation and reformation, which will detailed hereafter, are such profound institutional changes that the institutional fabric of taken-for-granted is torn and the inner workings of institutions and the intentions of actors are made available for all to see. In this respect, ANT offers a useful research methodology for extending our understanding of institutional working in regional environmental governance by problematizing the common view of institutions as concrete and enduring social structures, and furthermore, institutions are fictions actively created and recreated by actants [88].

\subsubsection{Uncertainty and Innovation and Reframing Targets of Regional Environmental Governance}

Here, the matrix of 'nine types of uncertainty' (abbreviated as 'matrix') designed by Dewulf and Biesbroek (2018) [44], which combines the three natures and the three objects of uncertainty, 
was adopted to address uncertainties of challenges facing regional environmental governance in the research area.

The matrix distinguishes the nature of uncertainty into three types [89-92]: Epistemic uncertainty, ontological uncertainty, and ambiguity. Epistemic uncertainty refers to uncertainty due to our lack of knowledge about a phenomenon and is therefore a characteristic of the human state of mind. More like the characteristic of the 'state of the world', ontological uncertainty $[92,93]$ refers to uncertainty due to the inherent variability in the phenomenon of interest, such that its chaotic behavior precludes full predictability. Ambiguity $[90,91]$ refers to uncertainty due to the simultaneous presence of multiple frames of reference about the phenomenon of interest, whereby it is a characteristic of the 'state of society'.

In parallel, understanding the uncertainties in decision-making is of paramount importance for decision making $[94,95]$. Thus, the distinction between substantive, strategy and institutional uncertainty is adopted to understand the object of uncertainty in the decision-making process $[91,96]$. Substantive uncertainty refers to uncertainty about the nature of the problems that are addressed in an environmental governance process and about their causes or solutions. Strategic uncertainty refers to uncertainty about the strategic choices made by actors involved in the governance process. Institutional uncertainty refers to uncertainty about the formal and informal rules of the game that apply in an environmental governance context [17].

Thereafter, the deficiencies and failures of regional environmental governance can be identified, and countermeasures regarding the innovation and reformation of regional environmental governance can be formulated accordingly.

\subsubsection{Institution Innovation and Reformation}

In this section, a transition circle was introduced for regional environmental governance transformation through a cyclical and iterative process. The circle is initiated by establishing and developing transition arenas focused on a specific transition theme: These constitute the basis of the management transformation process within the circle. After establishing these arenas, a vision or long-term goal for regional sustainable development needs to be generated: This process is done by encouraging imaginative and innovative transition images. Such images then are translated into transition goals, which should be qualitative (rather than quantitative), multi-dimensional, and represent the notion of sustainability. The next stage consists of undertaking transition experiments: these experiments should be inspired by and should reflect the transition visions and images, whereby such experiments could create a portfolio of examples that will reinforce each other and contribute to sustainability objectives in significant and measurable ways. Finally, monitoring and evaluation provide an 'enriched context' for transition management with regard to actors within the transition arena (e.g., who is doing what? Who is interacting with whom?) and transition agenda (e.g., actions performed, goals reached, projects undertaken, and instruments devised). The transition process itself should also be monitored, specifically addressing the rate of progress, the barriers and the countermeasure to be improved.

\section{Materials and Methods}

In this section, procedures of method were detailed after a brief introduction of the research area. There were four logically associated parts based on ESV based AGM (Figure 2). Firstly, spatial and temporal ESV pattern was detected, and then, actuality analysis was performed in order to comprehend the status quo of regional environmental governance in the research area. Thereafter, uncertainties of regional environmental governance failures were analyzed as well as countermeasures for addressing these uncertainties were proposed. Based thereon, an adaptive institution transition model was provided for regional governance innovation and reformation. 


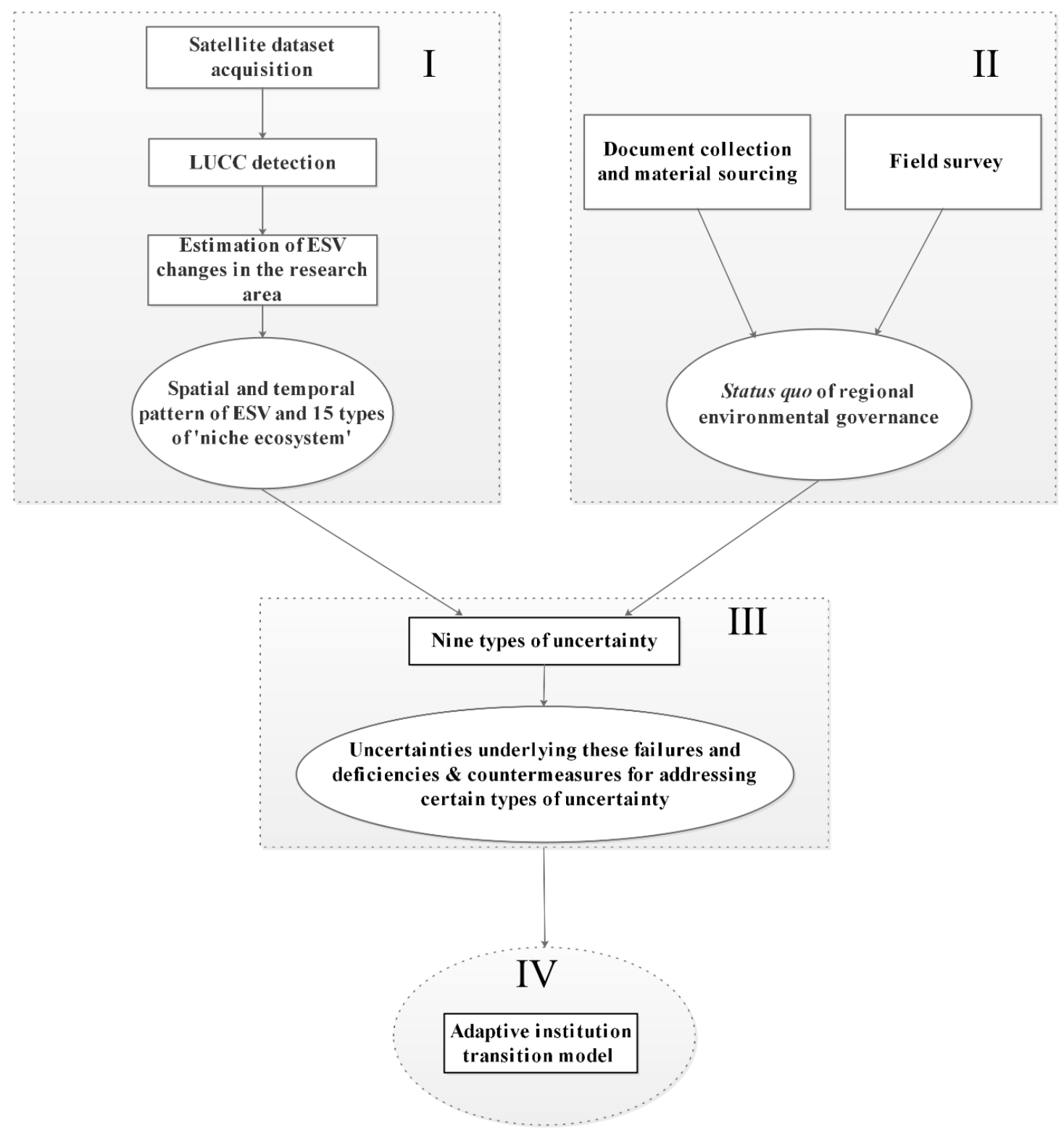

I. The spatial and temporal pattern of ESV changes

II. Actuality analysis of regional environmental governance

III. Uncertainty \& innovation and reframing targets of regional environmental governance

IV. Institution innovation and reformation

Figure 2. Summary figure of the research design. LUCC: land use and land cover change; ESV: ecosystem services value.

\subsection{Research Area}

The research area is situated in the climate transition zone between the north temperate zone and the subtropical climate zone (Figure 3). It has four distinct seasons, a wet climate, and a long frost-free period (Table 1). Mountainous terrain accounts for $79 \%$ of the research area, hilly terrain accounts for $18 \%$, and river valley accounts for only $3 \%$. Given such unique geographical and climatic conditions, the ecosystems here are extremely fragile. For example, 53.8\% of the research area has undergone severe soil erosion according to the results of the 2nd National Land Resource Investigation in China [97]. 


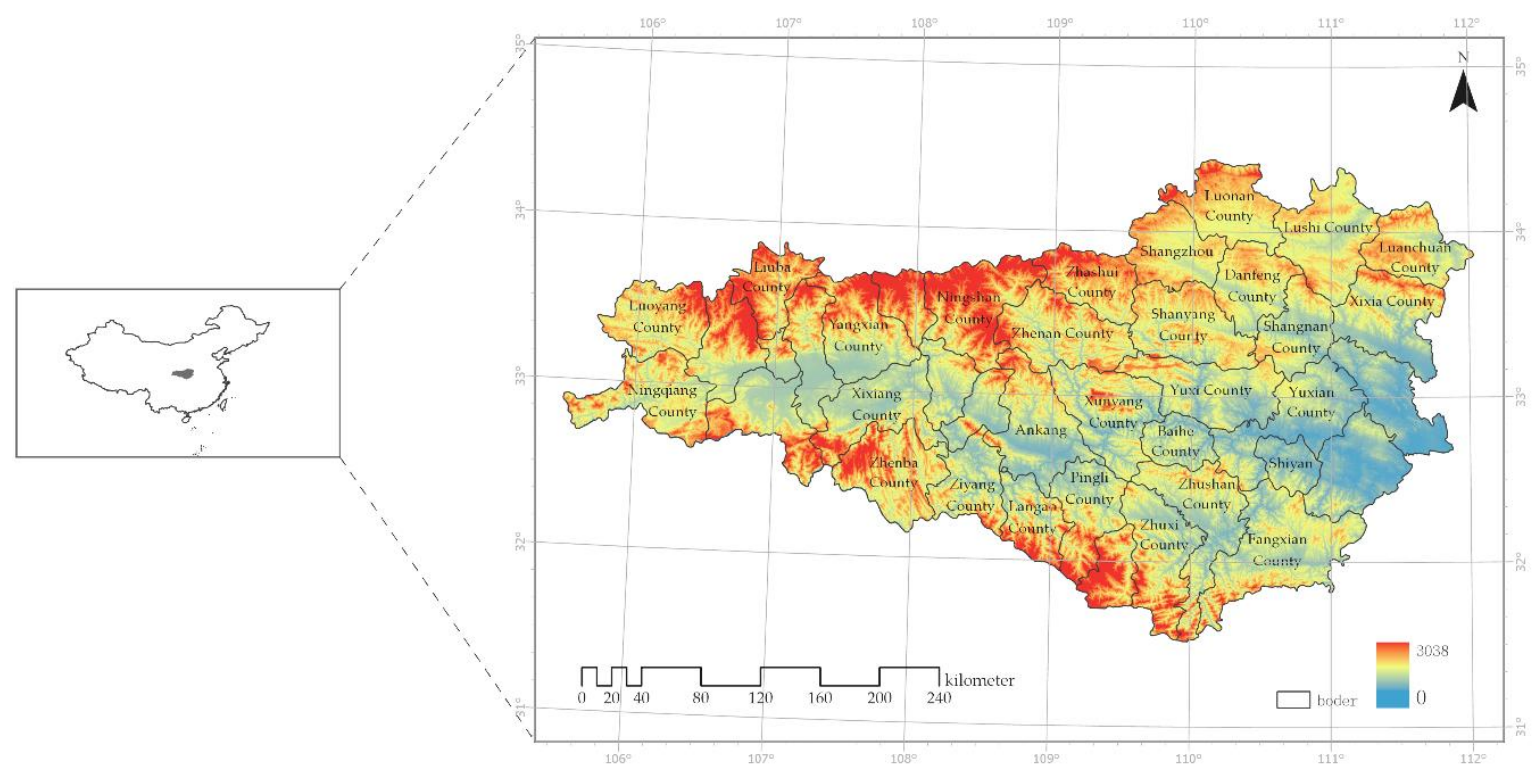

Figure 3. Location of the research area. The water source area (WSA) of the MRP $\left(31^{\circ} 31^{\prime} \mathrm{N}\right.$ to $34^{\circ} 25^{\prime} \mathrm{N}$, $105^{\circ} 31^{\prime} \mathrm{E}$ to $112^{\circ} 2^{\prime} \mathrm{E}$ ) corresponds to the upstream region of the Han River (a tributary of the Yangtze River) and the Dangiiangkou Reservoir, and comprises 40 counties belonging to 7 different municipalities (Ankang, Shangluo, and Hanzhong in Shaanxi Province; Nanyang, Sanmenxia, and Luoyang in Henan Province; Shiyan in Hubei Province). Dominantly located in the Hanjiang and Danjiang river basins, there are 215 rivers with a drainage area of more than $100 \mathrm{~km}^{2}$ and 21 rivers with a drainage area of more than $1000 \mathrm{~km}^{2}$ in this region, accounting for $66.7 \%$ of the overall water resources in these two river basins ( 38.8 billion $\mathrm{m}^{3}$ ). This region received a per capita water supply of $3741 \mathrm{~m}^{3}$ in 2010 , which was approximately $170 \%$ of the national average level (2200 $\mathrm{m}^{3}$ water per capital) [98].

Table 1. Environmental conditions in the research area.

\begin{tabular}{|c|c|c|c|c|c|}
\hline Province & $\begin{array}{c}\text { Municipality/County } \\
\text { (County-Level City, } \\
\text { District) }\end{array}$ & Climate & $\begin{array}{c}\text { Annual Mean } \\
\text { Sunshine } \\
\text { (Hours) }\end{array}$ & $\begin{array}{c}\text { Annual Mean } \\
\text { Temperature } \\
\left({ }^{\circ} \mathrm{C}\right)\end{array}$ & $\begin{array}{c}\text { Annual } \\
\text { Precipitation } \\
(\mathrm{mm})\end{array}$ \\
\hline \multirow[t]{3}{*}{ Shaanxi } & Hanzhong & $\begin{array}{l}\text { Transition Zone between } \\
\text { North Temperate Zone } \\
\text { and Subtropical Zone }\end{array}$ & 1591 & 14 & $800 \sim 1000$ \\
\hline & Ankang & $\begin{array}{l}\text { Subtropical-Continental } \\
\text { Monsoon Climate }\end{array}$ & $1496 \sim 1836$ & $15^{1}$ & $750 \sim 1100$ \\
\hline & Shangluo & $\begin{array}{l}\text { Transition Zone between } \\
\text { North Temperate Zone } \\
\text { and Subtropical Zone }\end{array}$ & $1860 \sim 2130$ & 14 & 710 930 \\
\hline Hubei & Shiyan & $\begin{array}{c}\text { North } \\
\text { Subtropical-Continental } \\
\text { Monsoon Climate }\end{array}$ & 1655 1958 & 16 & More than 800 \\
\hline \multirow{4}{*}{ Henan } & $\begin{array}{l}\text { Lushi County } \\
\text { (Sanmenxia) }\end{array}$ & $\begin{array}{l}\text { Transition Zone between } \\
\text { North Temperate Zone } \\
\text { and Subtropical Zone }\end{array}$ & $1860 \sim 2130$ & 14 & $710 \sim 930$ \\
\hline & $\begin{array}{l}\text { Luanchuan County } \\
\text { (Luoyang) }\end{array}$ & $\begin{array}{l}\text { Transition Zone between } \\
\text { North Temperate Zone } \\
\text { and Subtropical Zone }\end{array}$ & $1860 \sim 2130$ & 14 & $710 \sim 930$ \\
\hline & $\begin{array}{l}\text { Xixia County } \\
\text { (Nanyang) }\end{array}$ & $\begin{array}{l}\text { Transition Zone between } \\
\text { North Temperate Zone } \\
\text { and Subtropical Zone } \\
\text { Temperate Zone and }\end{array}$ & $1860 \sim 2130$ & 14 & 710 930 \\
\hline & $\begin{array}{l}\text { Zhechuan County } \\
\text { (Nanyang) }\end{array}$ & $\begin{array}{l}\text { Subtropical Zone North } \\
\text { Subtropical-Continental } \\
\text { Monsoon Climate }\end{array}$ & 1655 1958 & 16 & More than 800 \\
\hline
\end{tabular}

\footnotetext{
${ }^{1}$ Except Ningshan and Zhenping County with a temperature of $12^{\circ} \mathrm{C}$.
} 
In 2010, the population in the research area was 14 million, while its per capita GDP was 15,813 CNY [99-102] (Appendix A), approximately $20 \%$ of the level of Beijing $(75,943$ CNY per capital) and $21 \%$ of that in Tianjin $(72,994$ CNY per capita) in the same period $[103,104]$. Due to this weak socio-economic base, the total investment in the fixed assets in the research area was only 189 billion CNY in 2010, less than 35\% of the investment of Tianjin (651.14 billion CNY) or Beijing (549 billion $\mathrm{CNY}$ ). Furthermore, the region's economic development pattern remains driven by, and locked into secondary industries (accounting for approximately 50\% of the regional GDP), which are fraught with low value-added, energy-extensive, and low-tech industries.

\subsection{Ecosystem Service Value (ESV) Variation and Spatial-Temporal Distribution Pattern}

To evaluate the ESV variation in the research area during the construction of the MR project, first, the LUCC between 2002 and 2010 was detected through the adoption of the LANDSAT TM5 datasets as well as other assistant materials [105]. Subsequently, the ESV variation in the research area between 2002 and 2010 was assessed by adopting the equivalent weighting factors of the ecosystem service per hectare for the terrestrial ecosystems in China by Xie et al. (2003) [106]. One unit of the coefficient in the scheme (Table 2) is equal to the average value of the natural food produced by one hectare of cropland per year, which is proposed to be equivalent to $1 / 7$ of the actual food production. According to Wang (2011) [107], the ESV of one equivalent weight factor in the research area was 1114.28 Yuan. The ESV of one unit of each land-use category was assigned based on the nearest equivalent ecosystem (Table 3), and six LUCC categories (forestland, cropland, wetland, water body, grassland and built-up land) (Appendix B) were detected in this research, among which the ESV of the built-up land set as 0 Yuan $\cdot \mathrm{ha}^{-1} \cdot \mathrm{yr}^{-1}$.

Table 2. Equivalent weighting factors of ecosystem services per hectare of China's entire terrestrial ecosystem (adopted from Xie et al., 2003) [106].

\begin{tabular}{|c|c|c|c|c|c|c|}
\hline Ecosystem Function & Forestland & Grassland & Cropland & Wetland & Water Body & Built-Up Land \\
\hline Climate Regulation & 2.7 & 0.9 & 0.89 & 17.1 & 0.46 & 0 \\
\hline Soil Formation and Retention & 3.9 & 1.95 & 1.46 & 1.71 & 0.01 & 0.02 \\
\hline Waste Treatment & 1.31 & 1.31 & 1.64 & 18.18 & 18.18 & 0.01 \\
\hline Biodiversity Protection & 3.26 & 1.09 & 0.71 & 2.5 & 2.49 & 0.34 \\
\hline Raw Material & 2.6 & 0.05 & 0.1 & 0.07 & 0.01 & 0 \\
\hline Recreation and Culture & 1.28 & 0.04 & 0.01 & 5.55 & 4.34 & 0.01 \\
\hline Total & 21.85 & 7.24 & 6.91 & 62.71 & 46.01 & 0.42 \\
\hline
\end{tabular}

Table 3. Annual ecosystem service value per unit area of each land use and land cover (LUCC) category in the research area ${ }^{*}\left(\right.$ Yuan $\left.\cdot \mathrm{ha}^{-1} \cdot \mathrm{yr}^{-1}\right)$.

\begin{tabular}{|c|c|c|c|c|c|c|}
\hline Ecosystem Function & Forestland & Grassland & Cropland & Wetland & Water Body & Built-Up land \\
\hline Climate regulation & 3009 & 1003 & 992 & 19,054 & 513 & 0 \\
\hline Soil formation and retention & 4346 & 2173 & 1627 & 1905 & 11 & 0 \\
\hline Waste treatment & 1460 & 1460 & 1827 & 20,258 & 20,258 & 0 \\
\hline Biodiversity protection & 3633 & 1215 & 791 & 2786 & 2775 & 0 \\
\hline Raw material & 2897 & 56 & 111 & 78 & 11,143 & 0 \\
\hline Recreation and culture & 1426 & 45 & 11 & 6,184 & 4836 & 0 \\
\hline Total & 24,347 & 8067 & 7700 & 69,877 & 62,356 & 0 \\
\hline
\end{tabular}


Thereafter, the ESV of each ecosystem was estimated based on its equivalent LUCC categories by Equation (1), and the ESV of each corresponding ecosystem service function, and the total ESV of the research area were also calculated by Equations (2) and (3).

$$
\begin{gathered}
E S V_{k}=\sum_{f} A_{k} \times V C_{k f} \\
E S V_{f}=\sum_{k} A_{k} \times V C_{k f} \\
E S V=\sum_{k} \sum_{f} A_{k} \times V C_{k f}
\end{gathered}
$$

where $E S V_{k}, E S V_{f}$, and $E S V$ refer to the $E S V$ of LUCC category ' $k$ ', the value of ecosystem function type ' $f$ ' and the total $E S V$ of the research area respectively. $A_{k}$ is the area occupied by the LUCC category ' $k$ ', and $V C_{k f}$ is the value coefficient (Yuan'ha $\left.{ }^{-1} \cdot \mathrm{a}^{-1}\right)$ for the LUCC category ' $k$ ' and the ecosystem service function type ' $f$ '.

The spatial distribution pattern of the ESV as well as the regions with ecosystems converted to ecosystems proxied by built-up land and cropland between 2002 and 2010 were also detected in the research area.

\subsection{Uncertainty of Regional Environmental Governance and Institution Innovation and Reframing Through a Transition Circle}

According to the hierarchical governmental levels in China [108], the spectrum of regional governance in the research area is composed of the supra-regional, regional, and sub-regional levels of administrative authorities. The first two levels include the central government and regional governments in the beneficiary regions (BRs) of the MRP (including Hebei and Henan provinces, and Beijing and Tianjin municipalities), while the sub-regional level denotes the local governments in the research area, i.e., the municipal and county/district levels.

Due to the similar 'development dilemma' of developing countries in the research area, the causes of failures and deficiencies in regional environmental governance are numerous, including incoordination and inconsistency of sub-regional development strategies and plans with high-level ones, intentional ignorance, or deliberate delays in achieving the regional environmental targets, mismatches between existing local socio-economic structures and institutions in accordance with changes in regions' developmental goals, and misunderstandings and unwillingness to cooperate by local communities. Therefore, cross-scale policy interactions to identify flaws and deficiencies of regional environmental governance was adopted through both document collection and material sourcing on the regional formal institutions and field survey to comprehend the status of the informal institution in the research area.

To facilitate such cross-scale policy interaction process, 15 types of 'niche ecosystem' regions represented by six LUCC-based ecosystems and nice ecosystem function-based ecosystems were identified. These 'niche ecosystem' regions were spatially verified based on the variation and spatial distribution dynamics of ESVs in the research area, based on which, the failures and deficiencies of regional environmental governance were identified through comparing between the spatial and temporal pattern of the regional $E S V$ variation against the ideal environmental governance objective of the research area, literally 'sustainable development'.

Subsequently, the uncertainties underlying these failures and deficiencies were revealed according to the matrix (Table 4). The nature and object of uncertainties that lead to such failures and deficiencies can be identified, and countermeasures for addressing certain types of uncertainty can be proposed. For instance, the 'substantive epistemic uncertainty' - the lack of knowledge about the substance of an environmental governance issue, can be addressed by strategies and endeavors that enrich knowledges and information about this issue. 
Table 4. Nine types of uncertainty (sourced from Dewulf and Biesbroek (2018) [44]).

\begin{tabular}{|c|c|c|c|}
\hline \multicolumn{4}{|c|}{ Type of Uncertainty } \\
\hline Object of Uncertainty & Epistemic & Ontological & Ambiguity \\
\hline Substantive & $\begin{array}{l}\text { Lack of knowledge about the } \\
\text { substance of the issue (e.g., } \\
\text { what is the level of water } \\
\text { pollution in the river?) }\end{array}$ & $\begin{array}{l}\text { Irreducible unpredictability } \\
\text { of the substantive issue (e.g., } \\
\text { how excessive will extreme } \\
\text { rainfall events be?) }\end{array}$ & $\begin{array}{l}\text { Different frames about the } \\
\text { substance of the issue (e.g., is } \\
\text { this water scarcity a water } \\
\text { supply or a water demand } \\
\text { problem?) }\end{array}$ \\
\hline Strategic & $\begin{array}{l}\text { Lack of knowledge about the } \\
\text { (inter)actions of actors (e.g., } \\
\text { what are the formal rules for } \\
\text { public-private partnerships) }\end{array}$ & $\begin{array}{l}\text { Irreducible unpredictability } \\
\text { of the (inter)actions of actors } \\
\text { (e.g., how will actor A } \\
\text { respond when publicly } \\
\text { accused of corruption?) }\end{array}$ & $\begin{array}{l}\text { Different frames about the } \\
\text { (inter) actions of actors (e.g., } \\
\text { is this a genuine proposal for } \\
\text { concentration or rather a } \\
\text { delaying tactic?) }\end{array}$ \\
\hline Institutional & $\begin{array}{l}\text { Lack of knowledge about the } \\
\text { rules of the game (e.g., what } \\
\text { are the formal rules for } \\
\text { public-private partnership?) }\end{array}$ & $\begin{array}{l}\text { Irreducible unpredictability } \\
\text { of the rules of the game (e.g., } \\
\text { how will the upcoming } \\
\text { elections affect the } \\
\text { environmental regulation?) }\end{array}$ & $\begin{array}{l}\text { Different frames about the } \\
\text { rules of the game (e.g., how } \\
\text { should the precautionary } \\
\text { principle be applied to this } \\
\text { specific case?) }\end{array}$ \\
\hline
\end{tabular}

Based on all these uncertainties and countermeasures, issues for regional institutional innovation and reformation were identified by cross-checking the innovation arenas with the status quo of environmental governance in the research area.

Based thereon, an adaptive institution transition model in terms of a transition circle for regional institutional innovation and reformation was introduced in this research. This theoretical framework consists of four independent but interconnected components [109]: (1) Structure the problem in question, develop a long-term vision for regional sustainability governance, and establish and organize transition arenas of regional environmental governance; (2) develop future images and a transition agenda and derive necessary transition path; (3) establish and carry out transition experiments and mobilize the resulting transition networks; and (4) monitor, evaluate, and learn lessons from the transition experiments and, based on these, make adjustments in the vision, agenda, and coalitions.

\section{Results}

\subsection{Spatial and Temporal Pattern of ESV Variation in the Research Area}

The total ESV of the research area decreased from approximately 228 billion CNY in 2002 to 222 billion CNY in 2010 (Table 5). From 2002 to 2010, the ESV of cropland, wetland and water bodies increased significantly, with net increases of approximately 4,7 , and 4 billion CNY respectively. However, such increments were offset by the decrement of $E S V$ proxied by the forestland in the same time frame, by approximately 21 billion CNY. Additionally, the expansion of the built-up land during the research period also had a negative contribution to the overall $E S V$ of the research area.

Table 5. Ecosystem service value (ESV) variation in the research area between 2002 and 2010.

\begin{tabular}{lcccccccc}
\hline & & Forestland & Grassland & Cropland & Wetland & $\begin{array}{c}\text { Water } \\
\text { Body }\end{array}$ & $\begin{array}{c}\text { Built-Up } \\
\text { Land }\end{array}$ & Total \\
\hline & 2002 & $19,445,514$ & 78,198 & $1,628,627$ & $1,228,541$ & 418,481 & 0 & $22,799,361$ \\
& 2010 & $17,376,338$ & 66,338 & $2,064,497$ & $1,889,985$ & 775,584 & 0 & $22,172,743$ \\
ESV 2002-2010 & $(104$ Yuan $)$ & $-2,069,176$ & $-11,860$ & 435,871 & 661,444 & 357,103 & 0 & $-626,619$ \\
$\left(104 Y u a n \cdot \mathrm{yr}^{-1}\right)$ & $(\%) \mathrm{a}$ & -10.64 & -15.17 & 26.76 & 53.84 & 85.33 & 0 & -2.75 \\
& $\left(\% \cdot \mathrm{yr}^{-1}\right)$ & -1.33 & -1.90 & 3.35 & 6.73 & 10.67 & 0 & -0.34 \\
\hline
\end{tabular}

From the perspective of ecosystem types, five ecosystems with positive ESVs (proxied by the LUCC categories of forestland, grassland, wetland, cropland and waterbody) can be grouped into three groups: high-contribution ecosystems, including ecosystems proxied by wetland and water bodies. The areas of wetland and water bodies accounted for only $2.6 \%$ and $1.4 \%$ of the total area, 
respectively, while the ESVs of these ecosystems accounted for approximately about $8.5 \%$ and $3.5 \%$, respectively in 2010. Then, there are medium-contribution ecosystem including the ecosystems proxied by forestland. The proportion of the area classified as forestland (67.3\%) is smaller than its contribution (78.4\%) to the regional ESV in the research area in 2010. Finally, there are low-contribution ecosystems, including ecosystems proxied by cropland and grassland. Cropland and grassland occupied $25.3 \%$ and $0.8 \%$ of the entire area, and contributed only $9.3 \%$ and $0.3 \%$ of the total ESV in the research area in 2010, respectively.

The fluctuation of contributions of each ecosystem service function $\left(E S V_{f}\right)$ to the overall regional ESV was small, with small changes in their ranks between 2002 and 2010 (Table 6). The overall ranked order of $E S V_{f}$, in decreasing rank, was soil formation and retention, water supply, gas regulation, climate regulation, biodiversity protection, waste treatment, raw material, recreation and culture, and food. The top two $E S V_{f}$ were of the most significance for maintaining the quality and quantity of water resources in the research area. According to the ranks, the top six $E S V_{f}$ jointly accounted for more than $80 \%$ of the entire $E S V$ of the research area. In contrast, the $E S V_{f}$ of food, as the last in the ranked order, contributed less than $2 \%$ of the research area's total ESV.

Table 6. Ecosystem services value of the ecosystem service functions in the research area in 2002 and 2010 *.

\begin{tabular}{|c|c|c|c|c|c|c|c|c|}
\hline \multirow{3}{*}{ Ecosystem Function } & \multicolumn{3}{|c|}{2002} & \multicolumn{3}{|c|}{2010} & \multirow{3}{*}{$\begin{array}{c}\text { Over-All } \\
\text { Rank }^{b}\end{array}$} & \multirow{3}{*}{ Tendency $^{c}$} \\
\hline & $E S V_{f}$ & \multirow{2}{*}{$\%^{a}$} & \multirow{2}{*}{ Rank } & $E S V_{\mathrm{f}}$ & \multirow{2}{*}{$\%$} & \multirow{2}{*}{ Rank } & & \\
\hline & $\left(10^{4}\right.$ Yuan $\left.^{\prime} \mathrm{yr}^{-1}\right)$ & & & $\left(10^{4}\right.$ Yuan $\left.\cdot y^{-1}\right)$ & & & & \\
\hline Gas regulation & $3,276,592$ & 14.37 & 3 & $2,994,359$ & 13.50 & 3 & 3 & $\downarrow$ \\
\hline Climate regulation & $2,961,555$ & 12.99 & 5 & $2,944,471$ & 13.28 & 4 & 4 & $\downarrow$ \\
\hline Water supply & $3,487,095$ & 15.29 & 2 & $3,542,399$ & 15.98 & 2 & 2 & $\uparrow$ \\
\hline Soil formation and retention & $3,869,586$ & 16.97 & 1 & $3,607,274$ & 16.27 & 1 & 1 & $\downarrow$ \\
\hline Waste treatment & $2,088,184$ & 9.16 & 7 & $2,398,412$ & 10.82 & 6 & 6 & $\uparrow$ \\
\hline Biodiversity protection & $3,152,011$ & 13.82 & 4 & $2,932,004$ & 13.22 & 5 & 5 & $\downarrow$ \\
\hline Food & 334,715 & 1.47 & 9 & 391,773 & 1.77 & 9 & 9 & $\uparrow$ \\
\hline Raw material & $2,339,454$ & 10.26 & 6 & $2,100,278$ & 9.47 & 7 & 7 & $\downarrow$ \\
\hline Recreation and culture & $1,290,168$ & 5.66 & 8 & $1,261,772$ & 5.69 & 8 & 8 & $\downarrow$ \\
\hline Total & $22,799,361$ & 100.00 & & $22,172,743$ & 100.00 & - & - & - \\
\hline
\end{tabular}

* The water source area of the Middle-Route project of the South-North Water Diversion project. ${ }^{\text {a }}$ The proportion of $E S V$ of certain ecosystem functions in the total $E S V$ in the same year. ${ }^{b}$ Overall rank refers to the order of the average $E S V$ of each ecosystem service function in 2002 and 2010. " An upward arrow " $\uparrow$ " denotes an increasing contribution, a downward arrow " $\downarrow$ " denotes a decreasing contribution, and a dash " - " indicates no change.

Apart from the southeastern-central regions, the ESV in the rest of the central region of the research area generally demonstrated a slowly descending trend between 2002 and 2010 (Figure 4). Regions with the highest $E S V$ (over 40,000 Yuan) were generally located in the southeastern part of the research area, including the Danjiangkou Water Reservoir and its adjacent regions, as well as in some river basins. Regions covered by forestland accounted for the second highest $E S V$ (between 20,000 and 40,000 Yuan). These regions were dominantly distributed in the northern part of the research area along the Qinling Mountains and the southern part of the Bashan Mountains. As for the crops and the grasslands, with an ESV between 5000 and 20,000 Yuan per square kilometer, were generally distributed in regions adjacent to urbanized areas, on the plateaus in mountainous terrain, and in the mountain valleys. Urbanized regions in the research area possessed the lowest ESV (less than 5000 Yuan). From 2002 to 2010, their spatial distribution pattern transformed from being concentrated in several major cities (i.e., Hanzhong, Ankang, Shiyan) to a more scattered spread pattern, with several urbanized agglomerations located in the western (Hanzhong and its adjacent urbanized area), central (Ankang and its adjacent urbanized area) and eastern regions (Shiyan and Dangiiangkou and their adjacent urbanized areas) of the research area. 


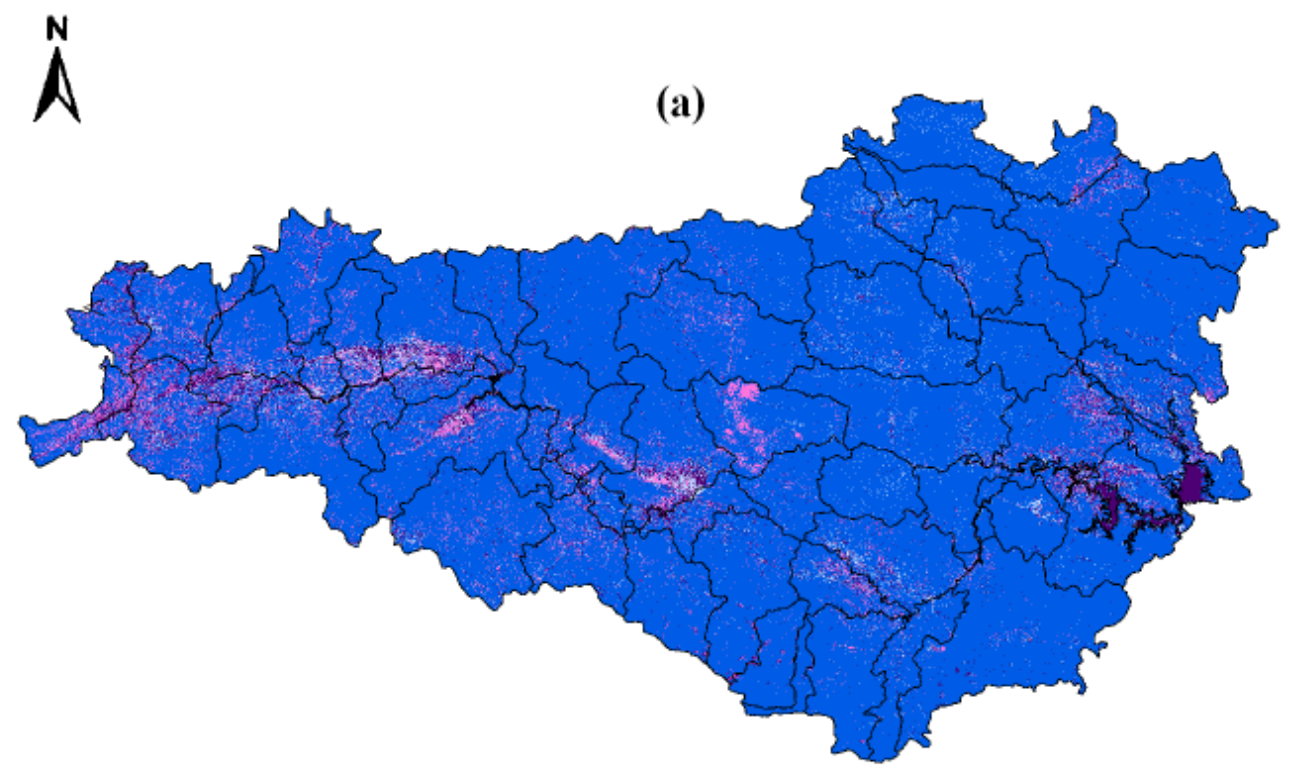

(b)
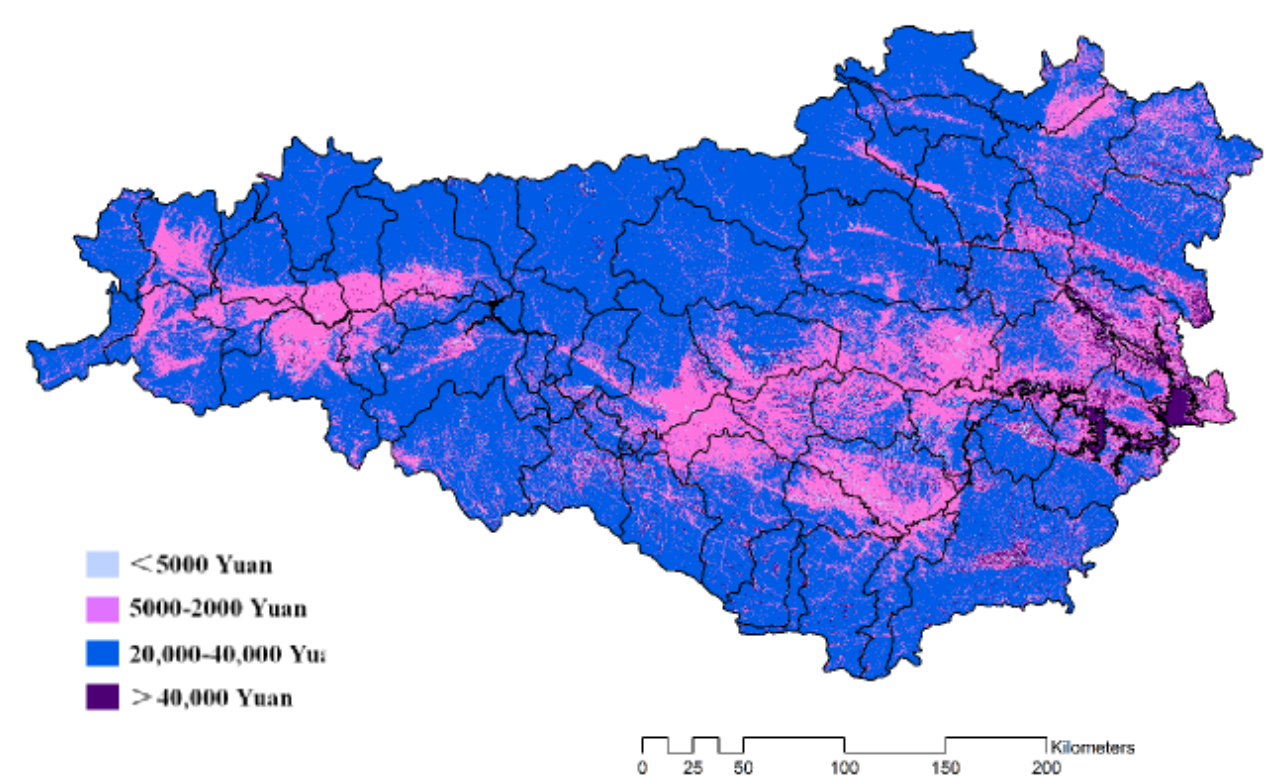

Figure 4. Spatial distribution pattern of ecosystems service value $(E S V)$ in the research area between 2002 and 2010.

Land-use transformation to built-up land and cropland were the dominant factor that led to ESV losses in the research area. With zero contribution to the total ESV, the increase in the built-up land was dominantly converted from forestland $(69.1 \%)$. However, the forestland-converted built-up land was scattered and could hardly be identified on the map (Figure 5a) since such LUCC conversions occurred randomly at relatively small scales. Regions with built-up land converted from wetland could be identified in the eastern and western parts of the research area, with the two largest concentrations of such regions situated in Zhechuan and Zhushan counties. Regions with built-up land converted from cropland were concentrated in Ankang city and Hanyin, Xixiang and Yangxian counties along the Hanjiang River. Additionally, the largest region with built-up land converted from grassland was located in Xunyang County. 


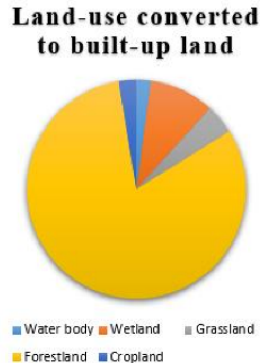

(a)
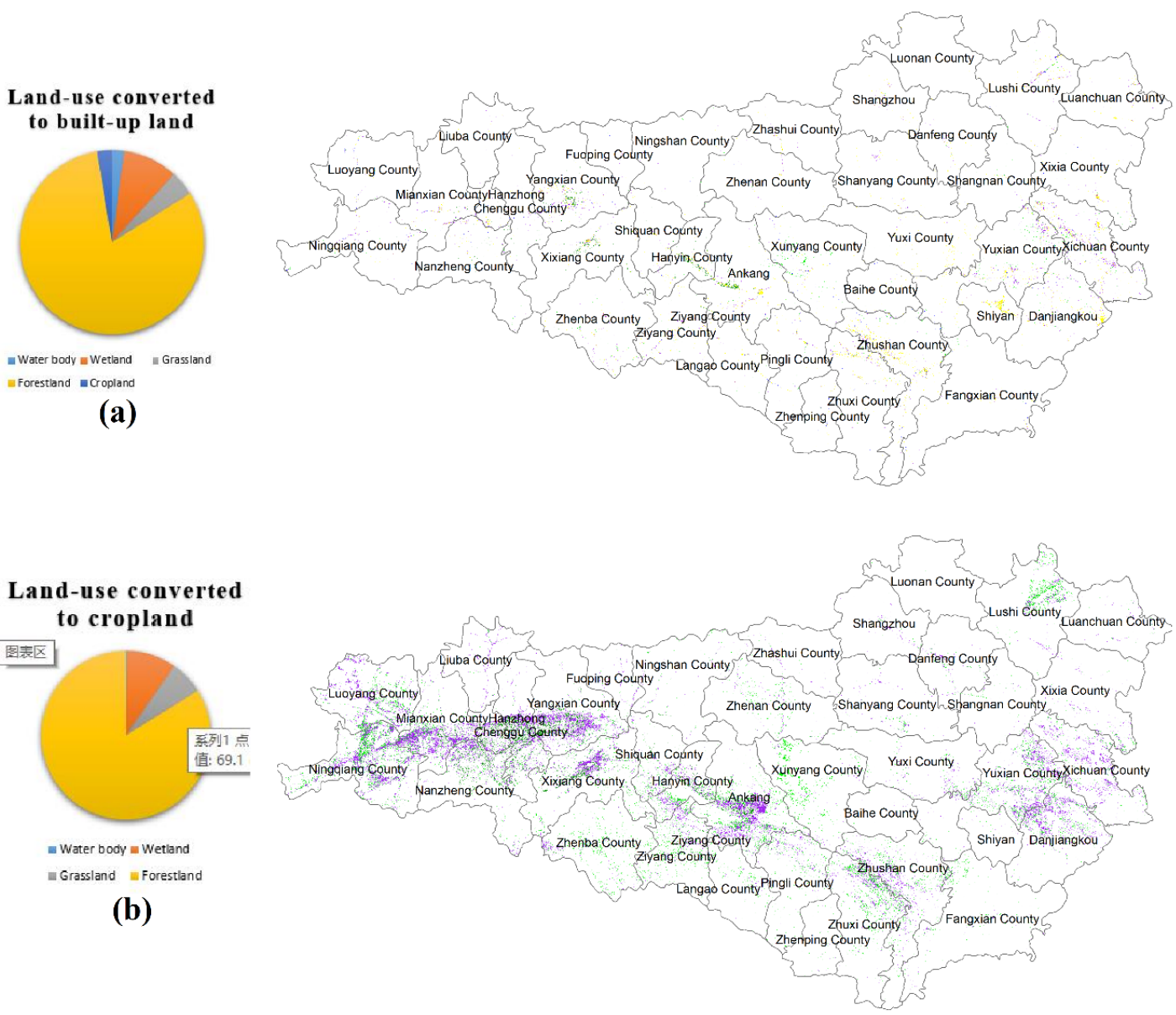

(b)
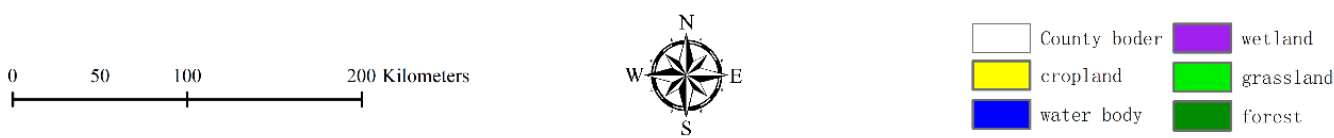

Figure 5. Spatial distribution of regions with LUCC categories converted to built-up land and cropland in the research area between 2002 and 2010.

The Figure $5 \mathrm{~b}$ delineates the distribution of the LUCC categories that were converted to cropland in the research area between 2002 and 2010. The main LUCC categories that converted to cropland were wetland, forestland, and grassland, among which wetlands were dominantly located in the western (Hanzhong city and its adjacent regions), east-central (Dangjiangkou city and two adjacent counties to its north), and west-central (Ankang city and its adjacent regions) regions of the research area along the Hanjiang River basin, while forestland and wetlands scattered along the Danjiang River basin in Lushi County.

\subsection{Status Quo of Regional Environmental Governance}

Covering a spectrum of issues with social, economic, and environmental aspects, the main task for regional environmental governance in the research area is to maintain the quantity and quality of water from the WSA of MRP diverted to the BR of MRP and eventually facilitate the social-ecological development pattern of the research area transforming towards sustainable fashion.

Based on the theorical framework built for this research, the status quo of the regional environmental governance in the research area was depicted from a three-pillar perspective of governance: Actor, institution and governance mode. 


\subsubsection{Actor}

Actor of regional environmental governance in the research area was composed of two principle components: State and non-state actors.

There were two types of state actors: governments (and their affiliated institutions) in the regular hierarchical chain of governance, and ad hoc government agencies from central government to the township government levels. The former type could be further divided into three categories, including governments at the national, provincial, and prefecture and county levels. At the national level, the State Council and its corresponding authorities issued a series of policies, legislations, and regulations that were closely related to environmental governance in the research area. Governments at the provincial level were responsible for implementing instructions, policies, laws, and regulations that were directly issued from higher command chains. Meanwhile, they had to develop plans, formulate polices and issue regional regulations for regional authorities within their jurisdiction. Governments at the prefecture and county levels were more involved in the execution of policies, regulations, laws, and development plans. It was also at this level that comments and suggestions on regional environmental governance were feedback to higher authority levels from local communities. For the latter type, ad hoc governmental agencies were specifically established for coordinating and solving cross-regional and multi-level issues related to the construction and operation of the MRP of SNWDP, such as coordinating cross-regional issues related to the construction of MRP, supervising and guiding the project construction, and addressing the livelihood issues of local communities. Such agencies include the South-North Water Diversion Project Construction Committee of the State Council (abbreviated as 'South-North Committee' thereafter) at the national level, and the Leading Group of the Middle Route Project of South-North Water Diversion Project Construction (abbreviated as 'Leading Group') at the provincial, prefecture and county levels.

Non-state actors also played a crucial role in regional environmental governance, and these actors included local enterprises and businesses, democratic parties, universities and research institutions, and civil society. Using local enterprises and businesses as an example, their roles in regional environmental governance in the research area were diversified. Those enterprises and businesses relied on the possession of local primary resources and backward technology and process were no longer perceived as active contributors in the local economy but rather as creators of environmental burden. In contrast, other enterprises and businesses requiring the maintenance of local natural ecosystems, for instance companies focused on eco-tourism, were becoming more active contributors in regional environmental governance because their business philosophy was more closely connected with local development pattern transformation visions.

\subsubsection{Institutions}

Institutions, as depicted by classical institutionalists as providers of 'expectations, stability, and meaning that are essential to human existence and coordination (Vatn 2005, p. 60) [110]', are the formal and informal rules and norms that organize the social, political, and economic relations [111].

The formal institution in the research area, as linked to the official channels of governmental bureaucracy [73,112], could be grouped into three types. The first type were regulations (regulatory documents) that were drafted and enacted by the State Council or departments of the State Council for regulating and administrating issues corresponding to the construction and operation of the MRP of the SNWDP at the national or cross-regional level. The scope of these institutions addressed was including investment and planning (investment management, project tendering, engineering design and bidding, etc.), financing and accounting (financing arrangement, contract management, investment control, etc.), construction management, environmental protection (specifically focused on regional water-soil conservation and water pollution prevention in the research area), land requisition and resettlement (land requisition and resettlement, heritage preservation, etc.), and supervision and administration. The second type included laws with regard to the complex context of environmental issues, which included at least 20 different topics covered by various laws related to regional environmental governance in the 
research area. Institutions in the third type were local regulations, which were drafted and enacted by local governments at the provincial or prefecture level, that addressed a range of issues related to environmental governance in the research area.

The informal institutions in this research were socially shared rules that outside the legally sanctioned channels, which includes folk customs and religious beliefs. The local folk custom in the research area was dominantly with respect to demonstrate reverence and honor from local communities to the nature, since the research area was largely located in mountainous regions. In contrast, the religious beliefs in the research area, with a much stronger influence on cultural-cognitive issues [113-115], were more involved with everyday life of local residents (e.g., house building, travelling, funeral, wedding, family formation) but less related to issues, such as ecosystem conservation and environmental protection.

\subsubsection{Governance Mode}

According to three primary modes of social organizations, i.e., the state, market and networks, representing alternative ways of organizing society in the research area, the corresponding governance modes were bureaucratic hierarchies, markets, and networks. In bureaucratic hierarchies, regulatory processes were mainly based on formal institutions and governmental actors played the dominant role. Markets were based on a combination of the formal and informal institutions and the non-state actors were dominant. Networks were largely governed by the informal institutions, and both the state and non-state actors participated [116].

\subsection{Regional Environmental Governance Uncertainties and Innovation Arenas}

\subsubsection{Challenges in Regional Environmental Governance}

To address challenges in regional environment governance, multi-level interactive analysis was performed through the lens of two types of 'niche ecosystem' (NE) - LUCC-based NE and ecosystem service function $\left(\mathrm{ES}_{\mathrm{f}}\right)$ based-NE.

From the perspective of LUCC-based NE, the increase in NE of the built-up land, as the key reason for the decreasing ESV, was dominantly converted from forestland and arable land, and a small portion from wetland. Because the amount of population concentrated in the research area was relatively steady between 2002 and 2010 (Appendix A), the main drivers of such LUCC conservation trend were the rapid expansion of the urbanized area, which was induced by the impulses of economic development and the sharp growth of the infrastructure construction. However, the living standard of local residents, characterized by the per capita annual disposable income of urban households, increased at a relatively slow path with respect to the fast growth of fixed asset investment and urban expansion in the research area (Appendix A). Therefore, the main challenges were the noneffective expansion control of urban land use.

The NE of the cropland, as with the second largest area in the research area, was generally distributed in regions adjacent to the urbanized area, on the plateaus in mountainous terrain, and in the mountain valleys, and with a small portion converted from wetland and forestland along the Hanjiang River basin and in Lushi County. Two major challenges with respect to the pattern of NE of the cropland were featured by undesirable land structure (i.e., high proportion of low-yielding drylands but low proportion of high-yielding paddy fields) and inefficient distribution patterns. More specifically, paddy fields were concentrated in hilly and low mountainous areas, while drylands were distributed in dry, hypothermal, and sloped areas.

The NEs of the wetland and water body were of vital importance for ecosystem service conservation in the research area since the functionality and integrity of these two NEs guaranteed the quantity and quality of the water resources conserved in the research area. In the downstream area of the Danjiang River and Hanjiang River basins, the adjacent area of the NEs of the wetland and water body were largely transformed from the medium-contribution ecosystem to the low-contribution ecosystem, and 
some even to urbanized areas. Such ecosystem transition pattern introduced a great regional ecosystem risk of soil erosion and degradation, which may eventually endanger the quantity and quality of the water resources reserved in this region.

There were nine types of $\mathrm{ES}_{\mathrm{f}}$-based NEs in the research area: Soil formation and retention, water supply, gas regulation, climate regulation, biodiversity protection, waste treatment, raw material, recreation and culture, and food.

In general, most ecosystem functions in the research area showed a downward trend in their ESV during the research period. Soil formation and retention and water supply were two crucial ecosystem functions for retaining the quality and quantity of water resources diverted to Northern China, yet for all that, the ESV of these two NEs in the research area slightly decreased between 2002 and 2010. As for gas emission regulations, climate regulation, and biodiversity protection, the beneficial areas of these three ecosystem functions occupied a much larger scale than the research area, and the ESVs of these NEs also demonstrated a descending trend. The beneficial area of waste treatment, raw material, recreation and culture, and food supply were comparatively narrowed at the local level, and the ESVs of these NEs in the research area demonstrated a diversified trend. As with the direct relationship with local environmental daintiness and comfortability, the ESV of NE of water treatment increased between 2002 and 2010. The NE of recreation and culture was vital for the regional development path transformation towards sustainable development, yet, with its ESV demonstrated a decreasing trend.

\subsubsection{Uncertainties and Innovation Arenas of Regional Environmental Governance}

Environmental issue governance is challenging not only because of the technical complexity in comprehending the complex nature of environmental issues, but also because of the social complexity of actor groups from a range of different backgrounds and because of the complexity of the institutional setting in which these decisions are made [96]. Therefore, the 'nine types of uncertainty' matrix adopted in this research is helpful to attribute challenges to certain uncertainty types that lead to or were rooted underlying local environmental governance challenges, based on which the more precise and targeted regional environmental governance innovation arenas could be identified.

Through the mirror of the 'matrix', the underlying uncertainties of challenges caused by the land-use conversion could be attributed to ambiguity-institutional (different frames about the rules of the game) and ambiguity-strategic (different frames about the actions of actors).

Along with prevalent rapid urbanization process in the research area, regions in this area have been through diverse land-use conversion process, featured by heterogeneous spatial distribution pattern and various land-use conversion types towards built-up land or cropland, as well as showed fragmented and inconsistent institutional foci in order to address such environmental governance challenges. Due to the fragmented (hierarchical) regional governmental regime, the regional institutions related to ES conservation at the sub-regional level in the research area demonstrated differentiated concerns. More specifically, Hubei Province and Henan Province, as co-occupiers of the Danjiangkou Water Reservoir, emphasized different policy foci. The institutions of Shiyan Municipality in Hubei Province highlighted pollution eradication in adjacent areas of the Danjiangkou Water Reservoir, while the institutions of the sub-regions within the territory of Henan Province, including Luanchuan, Zhechuan, Lushi and Xixia counties, paid more attention to immigration resettlement. However, Zhechuan County and Zhushan County, respectively, belonged to Henan Province and Hubei Province, representing the most significant loss of wetland that converted to built-up land. The institutions of Shaanxi Province, which occupied the largest number of counties in the research area, emphasized regional environmental protection and ecosystem conservation from the perspective of the entire province. Nonetheless, districts (belonging to Danjingkou city, Hanzhong city, Ankang city) and counties within the Hanjiang River basin (Hanyin county, Xixiang county, Yangxian county, and Xunyang county) represented the most rapid pace of ecosystem degradation, featured by land-use conversion from wetland to cropland and/or grassland. 
Local communities in the research area, as with different notions of their responsibility and duty in regional environmental governance, also played key roles in regional ecosystem degradation due to their anxious requirement of rapid socioeconomic development. The government-dominant rapid urbanization process has evoked diversified socio-economic demands while exerting huge pressures on local ecosystems, substantiated by a large amount of urbanized areas were converted from forestland for urbanized utilities, such as road, residential area, and commercial sites.

With respect to uncertainties underlaying LUCC variation, innovation arenas for regional environmental governance were elaborated as below.

Since the newly converted urban areas were dominantly concentrated in Hanzhong City, Ankang City, Shangluo City, Shiyan City, and Zhechuan County and Zhushan County, regional institutional innovation arenas for these regions should emphasize regional economic development pattern transformation, industrial structure adjustment, rigid control of urban sprawl, and comprehensive upgrading of public services. With regard to the challenges led by the NE of cropland, regional institutional innovation arenas should focus on the establishment of the Rural Land Circulation Mechanism, that is, to prevent soil erosion and promote land use efficiency in rural areas and upgrade the local agricultural industry towards technology-intensive and eco-friendly methods. Given the pressing scenario of rapid loss of ecosystem services due to urbanization, regional institutional innovation arenas should focus on ad hoc countermeasures of forest conservation and recovery, eco-compensation and transfer payment for water body and wetland conservation, and environmental education and involvement of local communities in decision-making processes related to environmental issues.

Through the lens of the 'matrix', the underlying uncertainty of the $E S V$ variation in soil formation and retention and water supply belonged to the ambiguity-institutional type, since the spatial jurisdiction scope of authorities in different governmental hierarchies were fragmented, and actors in these authorities stressed diversified environmental governance foci, which may lead to gaps in jurisdiction scope and vacancies in institutions while considering cross-scale environmental issues. Therefore, regional institutional innovation arenas with regard to these two NEs should bring the whole research area into the governance spectrum. Innovating and reframing efforts were including, at the central-government level, establishing plans for soil and water conservation, supervising the implementation of the plan, and formulating more detailed and operational guidance on the transfer payment from the central government to the research area; at the BR level, forming the mechanism of eco-compensation allocation for water resources conservation in the research area; at the sub-regional level of the research area, formulating strict rules/regulations to guarantee the effectiveness of water and soil conservation in these regions.

The uncertainty with respect to the NEs of gas emissions regulations, climate regulation, and biodiversity protection was epistemic-substantial, since knowledge on their intrinsic mechanisms that cause these environmental issues and their impacts on human beings were still not entirely clear, which weakens the effectiveness of institutions enacted to address them. Therefore, regional institutional innovation and reframing arenas for addressing these NEs, from a broader context at the central-government level, should enhance the financial support and favorable polices for conservation and reforestation of the natural forest and water conservation forest, and the ad hoc transfer payment mechanisms and policies for facilitating regional social-economic development transformation towards sustainable development.

Although the trend of the ESV of water treatment was increasing, there was still room for improving institutional arrangement addressing this issue, and the underlying uncertainty of this issue was epistemic-institutional. Therefore, regional institutional innovation arenas with regard to this NE should emphasize maintenance of local waste emission control and treatment, initiation of pollution rights trading, and guidance of the arrangement of the eco-compensation/transfer payment for water pollution treatment.

As with the most potential for diverting regional development transformation, uncertainty corresponding to the decreasing trend of the ESV of recreation and culture was epistemic-institutional. 
Specifically, the regional institutional innovation arenas considering this NE should highlight measures to provide preferential policies and financial support for evoking eco-tourism, and execute strict rules and regulations for pollution supervision and control.

Through cross-checking the innovation arenas against the existing institution system, arenas that were not covered by the existing regional governance institution were identified (Appendix C), and the portfolio for regional institutional innovation and reframing was formulated and cataloged below.

At the central-government level, future institutional innovation should focus on the transfer payment scheme for gas emissions regulation, climate change adaption, biodiversity conservation, establishing a pollution rights trading market, and facilitating regional development mode transformation in the research area. At the BR of the MRP level, institutional innovation should focus on not only the quality control of water resources in the research area, but also the share of eco-compensation assigned to each sub-region of the BR of the MRP, as well as the form of such eco-compensation (monetary or in kind). At the sub-regional level of the research area, institutional innovation should focus on formulating the phased targets for regional development mode transformation, formulating and supervising the performance of the rules/regulations on urban sprawl control, improving the public service facilities, drafting and enacting ad hoc regulations on waste treatment monitoring, initiating fiscal and policy supports for facilitating agro-industry advancement towards technology-intensive and eco-friendly fashions, advocating publicity and education on regional environmental protection and ecosystem conservation, and encouraging the involvement of local communities in the process of decision-making on environmental issues.

\subsection{Adaptive Transformation Model for Regional Institutional Innovation and Reframing}

With the portfolio for regional institutional innovation and reframing, an adaptive institution transition model in terms of cyclical and iterative processes was introduced to guide the adaptive transformation of the regional institutional system in the research area (Figure 6).

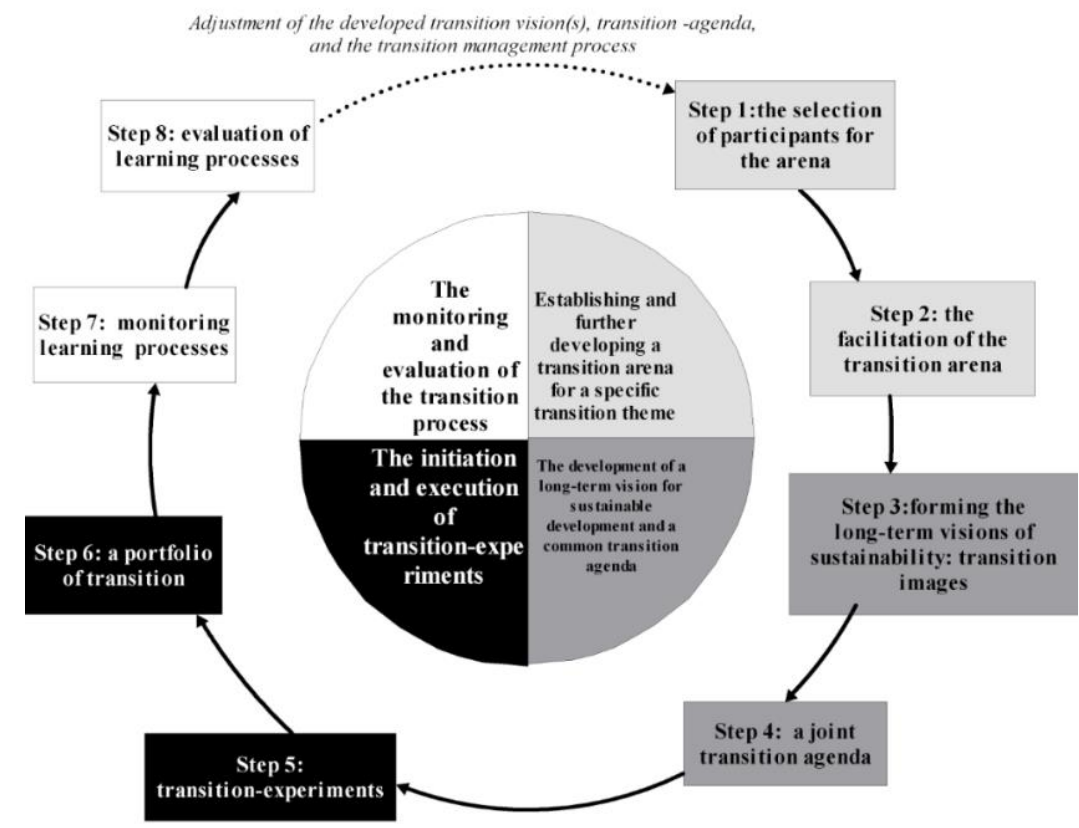

Figure 6. Adaptive institution transition model in terms of a transition circle for the environmental governance transition in the research area.

In the 1st stage (Figure 6), two steps are adopted to detect and frame the challenges of regional institution systems with respect to the long-term vision of regional development transformation. First, the regional development vision was articulated, and then the existing status of the regional 
institutional system was analyzed. Then, the existing regional governance status quo was analyzed from the perspective of institutions, roles of actor groups, and governance mode, as well as cross-scale policy interactions.

In the 2nd stage, two steps are taken to generate the new ESV-based agenda for regional institutional innovation and reformation. In step 3, the ESV variation assessment and regional institutional system analysis were performed to identify the innovation arenas. Thereafter, a joint transition agenda of the regional institutional system was sketched out in step 4 .

As for this research, the 1st and 2nd stages of the adaptive transition model were conducted through the ESV assessment and identification of the uncertainty and innovation arenas of regional environmental governance in the research area.

In the 3rd stage, measures are proposed to steer the regional institutions based on a transition portfolio. In step 5, the transition experiments shall be introduced in the 'typical' regions. In the research area, the transition experiment was undertaken in Shiyan through the implementation of the policy of the 'Demonstration Zone for Building Ecological Civilization (DZBEC)' by the State Council. Through this experiment, a bundle of institutional measurements were introduced, including the mechanism for establishing the eco-compensation, founding the national forest park system, and innovation of the regional coordination mechanism. This experiment was initiated in Shiyan in 2014 with a 5-year duration. Through the performance of this experiment, a portfolio of regional institutional innovation and reformation could be formulated and then duplicated to the rest part of the research area.

In the 4 th stage, two steps are necessary to monitor and evaluate the entire process of regional institutional system transformation. Steps 6 and 7 are required to monitor the regional social-economic development and $E S V$ variation trends to navigate such transformation towards the long-term vision of regional environmental governance transformation and readiness to be steered into the next round. In the case of the research area, strengthening the regional statistical work, enhancement of the oversight function of the local government, formulating strict standards for local environmental condition control and ecosystem conservation, and introducing the waste emissions and carbon trading market, are of profound significance for the success of the DZBEC project in Shiyan, as well as for sharing experiences with the rest of the world, especially ESAs in developing countries.

\section{Discussion}

\subsection{From Environmental Government to Governance}

A profound characteristic of the global implementation of environmental governance is the shift characterized as a transition from government to governance [117-120]. This shift reflects the fact that governments (which collectively are referred to as 'the state') no longer are, and in some cases cannot be, the sole sources of environmental decision-making authority [121,122]. Instead, through a host of mechanisms ranging from market to co-management arrangements, a diverse range of non-state actors (e.g., local enterprises and businesses, democratic parties, universities and research institutions, civil society) now play key roles in environmental governance.

Such importance of non-state actors in environmental governance denote a host of considerations, for instance limitations on the capacity of government agencies and pressure from citizens for a greater role in decision making [123,124].

To fulfill the aim of environmental governance in the research area, i.e., balance the geographic distribution of water resources, alleviate water scarcity in northern China, maintain the quantity and quality of ecosystems, and at the same time, shift the mode of regional development towards self-restraint and eco-friendly processes, it is necessary to adjust the present status of the actor network and governance mode in the research area to facilitate regional institutional innovation and reframing.

For the state actors, the governments and affiliated authorities at the national, provincial and local levels (municipal or county level) and the ad hoc governmental agencies of the MRP of the SNWDP 
from the national to local levels need to branch out their conventional jurisdictions to manage and coordinate cross-regional and multi-level environmental governance issues.

For the non-state actors, local enterprises and businesses need to not only adapt to their role shifting in regional environmental governance but also become proactive in the process of regional development mode transformation toward sustainability. Democratic parties, universities and research institutions should play more influential roles, for instance, in terms of professional think tanks, third-party participants, and so forth.

As another key component influencing regional governance, the governance mode refers to the extent and nature of involvement of the state and/or non-state actors in the governing activities [125]. In regard to environmental governance in the research area, the vertical hierarchical government regime is still in the dominant position. However, given that the lower governance levels are with much closer connection with the local communities and civil groups, it is necessary to listen to and involve them in the process of regional environmental governance. The advocacy and trial implementation of some other governance modes, such as self-governance or co-governing civil societies, can be a helpful supplement to the existing governance mode at the sub-regional level of environmental governance.

According to ANT, to perceive and manipulate institutional change demand researchers focus on manners in which actor networks grow in size, complexity and influence [88]. In the context of this research, institutional change to facilitate environmental governance transition can be achieved, besides addressing gaps and mismatches on existing formal and informal institutions, through focusing on the manner of actor network growth (in size, complexity, and influence) in a process composed of four moments of 'translation'(Denis et al. 2004, p. 7) [126]: 'problematization' -in which the main actors (both state and non-state) attempt to define and offer an 'obligatory passage point' for regional environmental governance, which generally was the founding of DZBEC project in the research area; 'interestement' - try to determine and fix the interests of key actors of regional environmental governance so that they are willing to stay with such process; 'enrolment' - main group of key actors are assigned 'roles' in environmental governance and drawn together to build an alliance; 'mobilization' - the actor network can be extended beyond an initial group.

\subsection{Transformation of Environmental Governance for Diverting Regional Development Towards Sustainability}

Although there are diversified reasons or initiatives, the common underlying goal of the transformation of environmental governance often includes more effectively responding to threats and opportunities [127], and diverting regional development towards sustainability, especially for developing economies [128].

However, transforming the regional environmental governance in the context of developing countries is not straightforward, which implies that such process will confront a host of challenges and questions, among which 'scale' and 'environmental equity' are two of the most pressing challenges in the process of transforming regional environmental governance in the context of developing countries.

'Scale' refers to both the resolution and the extent (or time period) at which the system is observed, including the temporal and spatial dimensions. Environmental decision-making in developing countries often faces the dilemma of mismatches between the scale of the politically defined system, e.g., city boundary, and the scope of environmental issues, e.g., climate change. The scale of a politically defined system is suitable for data collection and decision-making, while at the system boundary of environmental issues, most are associated with challenges, including insufficient data collection and discontinuous governance boundaries, which may significantly jeopardize the efficacy of environmental governance.

The integrated system of people and their living environment is continuously changing over a temporal scale. Most observable ecosystem phenomena and environmental problems occur in the context of continuous, short-or long-term changes associated with temporal and spatial scales. Because the environmental issues are characterized by homeorhetic stability (i.e., they return to a trajectory), rather than homeostasis (i.e., they return to some pre-disturbance state) [129], traditionally 
centralized governance models, from a social perspective, are not always suited to these dynamics, encouraging many to call for distributed (i.e., roles for state and non-state actors), adaptive and redundant institutional arrangements [25,64].

To address the dilemma caused by 'scale' challenges on environmental governance in the research area, countermeasures for governance advancement are necessary to involve the consideration of spatial fit-finding the appropriate spatial connection between governance and the environmental issues-and temporal fit-the inability to respond to external disturbances in a timely manner. According to the ESV-based AGM developed in this research, cross-scale and cross-level interactions of the human-environment system were thoroughly investigated by adopting the module I, i.e., evaluation of the spatial and temporal pattern of $E S V$ changes of various ecosystem types or different ecosystem service functions, and module II, i.e., actuality analysis of regional environmental governance through the lens of cross-scale policy interactions. Thereafter, the content extracted in module III, i.e., addressing the regional governance uncertainty and innovation and reframing targets of regional environmental governance, provide a task-specific, flexible intuitional innovation portfolio for promoting the transformation of environmental governance. Through the adoption of module IV, i.e., institution innovation and reframing through a transition circle, the relatively vague, intangible and scattered regional institutional transition goals are converted into more precise, tangible, and staged targets and diverted towards the desired end-state to facilitate the regional development mode transformation towards sustainability. Such a process is a goal-oriented (technological) transition [130], through which (different) goals or visions of the end-state are identified to guide actors and orient the strategic decisions of diversified actors.

To address another pressing issue on regional development transition towards sustainability-'environmental equity', countermeasures for addressing this issue, instead of underlining the nature of 'equity', invoke that outcomes of reginal environmental governance in the research area should refrain from or avoid [131-133]: (1) Policy effect inequalities-the unequal effect of environmental policy, i.e., the unequal distribution of, not only environmental goods or bads, but also the income effect among individual and groups led by regulations, tax policies, etc.; (2) impact inequities-the unequal environmental impact of the different individuals and groups with regards to their income and/or lifestyle [134]; (3) policy-making inequalities-the unequal access to environmental policy-making, i.e., the unequal involvement and empowerment of individuals and groups in decision regarding their immediate environment.

\section{Conclusions}

With the adoption of the framework developed in this research, the ESAs in developing countries can assess and identify limits and flaws of their regional environmental governance and then facilitate innovation and reformation of regional environmental governance to initiate regional development transformation towards sustainability. In this research, regional environmental governance in the research area was diverted towards distributed, adaptive and more specifically, suitable for regional sustainable development transition mode, following a series of logically connected and intrinsically ordered processes based on ESV-based AGM. Such processes included identifying deficiencies and failures of exiting regional environmental governance, deep digging of underlying uncertainties, cross-checking institution innovating arenas, establishing transition agendas, and ultimately, diverting regional environmental governance evolving in a circular manner.

The innovativeness of this research rests in the way that the measurement and assessment of ecosystem services are integrated into a wider framework of institutional change. Indeed, variations in ecosystem services from the perspectives of the different LUCC categories and ecosystem service functions, in terms of the ESV changes and patterns of its geo-distribution, are identified and measured and then treated as indicators or clues for directing regional institutional system transformation. Compared with traditional proposals for administrative change, the methodology proposed in this research is not prescriptive or directive: Rather, it is an approach for influencing the direction and speed 
of transition through a series of steering and coordination mechanisms, since regional development transitions in developing countries rest fundamentally on the interplay between many different processes (e.g., cultural changes, religious customs, social norms). Future efforts to improve the model outlined in this research could focus on the more comprehensive incorporation of marketing and planning mechanisms, as well as explore the consequences of geological transition for regional environmental governance in developing countries.

Author Contributions: Conceptualization, X.D. and W.Z.; Methodology, C.Z. and W.Z.; Writing—original draft preparation, X.D.; Writing — review and editing, X.D. and V.M.; Funding acquisition, X.D. and P.T.

Funding: This research was funded by the Humanity and Social Science Youth foundation of Ministry of Education of China, grant number 19XJCZH001, the Major Projects for the Key Research Base of Humanities and Social Sciences of the Ministry of Education, grant number 17JJD790015, and the National Social Science Fund of China, grant number 18XJY003.

Acknowledgments: The authors would like to thank two anonymous reviewers for their helpful and constructive comments that greatly contributed to improving the final version of this paper.

Conflicts of Interest: The authors declare no conflict of interest. 


\section{Appendix A}

Table A1. Social and economic conditions in the research area between 2002 and 2010*.

\begin{tabular}{|c|c|c|c|c|c|c|c|c|c|c|c|c|c|c|c|c|c|}
\hline \multirow[t]{2}{*}{ Province } & \multirow[t]{2}{*}{$\begin{array}{l}\text { Municipality/County } \\
\text { (County-Level City, } \\
\text { District) }\end{array}$} & \multicolumn{2}{|c|}{$\begin{array}{c}\text { Gross } \\
\text { Domestic } \\
\text { Production } \\
\text { (GDP) (100 } \\
\text { Million Yuan) }\end{array}$} & \multicolumn{2}{|c|}{$\begin{array}{c}\text { Population } \\
(10,000 \text { Persons })\end{array}$} & \multicolumn{2}{|c|}{$\begin{array}{c}\text { Per Capital GDP } \\
\text { (Yuan) }\end{array}$} & \multicolumn{2}{|c|}{$\begin{array}{c}\text { Total } \\
\text { Investment in } \\
\text { Fixed Assets } \\
\text { 100 Million } \\
\text { Yuan) }\end{array}$} & \multicolumn{2}{|c|}{$\begin{array}{c}\text { Per Capita Annual } \\
\text { Disposable Income } \\
\text { of Urban } \\
\text { Households (Yuan) }\end{array}$} & \multicolumn{2}{|c|}{$\begin{array}{l}\text { Per Capita Net } \\
\text { Income of } \\
\text { Rural } \\
\text { Residents } \\
\text { (Yuan) }\end{array}$} & \multicolumn{2}{|c|}{$\begin{array}{l}\text { Gross Output Value of } \\
\text { Agriculture, Forestry, } \\
\text { Animal Husbandry } \\
\text { and Fisheries (100 } \\
\text { million Yuan) }\end{array}$} & \multicolumn{2}{|c|}{$\begin{array}{l}\text { Ratio of } \\
\text { Primary, } \\
\text { Second and } \\
\text { Tertiary } \\
\text { Industries }\end{array}$} \\
\hline & & 2002 & 2010 & 2002 & 2010 & 2002 & 2010 & 2002 & 2010 & 2002 & 2010 & 2002 & 2010 & 2002 & 2010 & 2002 & 2010 \\
\hline \multirow{3}{*}{ Shaanxi } & Hanzhong & 129 & 510 & 369 & 382 & 3503 & 13,359 & 46 & 313 & 4577 & 14,509 & 1480 & 4,183 & 55 & 190 & 23:34:43 & 22:39:39 \\
\hline & Ankang & 81 & 327 & 293 & 304 & 2,768 & 10,747 & 31 & 530 & 4822 & 14,642 & 1417 & 3,976 & 42 & 116 & 27:27:46 & $20: 40: 40$ \\
\hline & Shangluo & 59 & 286 & 236 & 245 & 2489 & 11,677 & 22 & 290 & 4683 & 14,811 & 1258 & 3,605 & 31 & 100 & $27: 35: 38$ & 20:41:39 \\
\hline Hubei & Shiyan & 232 & 737 & 339 & 353 & 6850 & 22,054 & 46 & 406 & 5860 & 16,130 & 1714 & 3499 & 69 & 133 & 10:55:35 & $10: 55: 35$ \\
\hline \multirow{5}{*}{ Henan } & $\begin{array}{l}\text { Lushi County } \\
\text { (Sanmenxia) }\end{array}$ & 12 & 44 & 36 & 38 & 3348 & 11,579 & 4 & 49 & 5724 & 13,359 & 1616 & 3,809 & 7 & 19 & 28:35:37 & $19: 52: 29$ \\
\hline & $\begin{array}{l}\text { Luanchuan County } \\
\text { (Luoyang) }\end{array}$ & 15 & 142 & 32 & 34 & 4663 & 41,487 & 4 & 87 & & 14,469 & 1809 & 4,784 & 6 & 18 & $25: 42: 33$ & 8:77:15 \\
\hline & $\begin{array}{l}\text { Xixia County } \\
\text { (Nanyang) }\end{array}$ & 29 & 151 & 43 & 44 & 6742 & 34,754 & 7 & 112 & 5098 & 14,607 & 2136 & 6,512 & 15 & 37 & $31: 47: 22$ & $15: 65: 20$ \\
\hline & $\begin{array}{l}\text { Zhechuan County } \\
\text { (Nanyang) }\end{array}$ & 34 & 126 & 73 & 69 & 4750 & 18,713 & 8 & 100 & 4782 & 14,037 & 1446 & 4,237 & 20 & 49 & $33: 47: 20$ & $23: 56: 21$ \\
\hline & Total & 591 & 2323 & 1421 & 1469 & $4159^{a}$ & $15,813^{b}$ & 168 & 1887 & & & & & & & 21:42:37 & $17: 49: 34$ \\
\hline
\end{tabular}

* The water source area of the Middle Route project of the South-North Water Diversion project. ${ }^{\text {a }}$ The per capita GDP of the water source area of the Middle-Route project of the South-North Water Diversion project in 2002. ${ }^{6}$ The per capita GDP of the water source area of the Middle-Route project of the South-North Water Diversion project in 2010. 


\section{Appendix B}

Table A2. Land use and land cover (LUCC) categories in the research area.

\begin{tabular}{cl}
\hline Category & \multicolumn{1}{c}{ Definition } \\
\hline Forestland & $\begin{array}{l}\text { Forestlands have a tree-crown areal density (crown closure percentage) of 10\% or more, are stocked with trees capable of producing timber or } \\
\text { other wood products, and exert an influence on the climate or water regime. Land where trees have been removed so that the crown closure } \\
\text { is less than } 10 \% \text { but which have not been developed for other uses are included. }\end{array}$ \\
\hline Water Body & $\begin{array}{l}\text { Water bodies include watercourses (e.g., rivers, streams, canals, irrigation and drainage ditches, etc.) and stored water (reservoirs, lakes, } \\
\text { ponds, etc.) (The national standards of "classification of land use survey" in China (GB/T 21010-2007)). }\end{array}$ \\
\hline Wetland & $\begin{array}{l}\text { Wetlands are those areas where the water table is at, close to, or above the land surface for a significant part of most years. Examples of } \\
\text { wetlands include marshes, mudflats, and swamps situated on the shallow margins of bays, lakes, ponds, streams, and water-related structure } \\
\text { such as reservoirs. They include wet meadows or perched bogs in high mountain valleys and seasonally wet or flooded basins, playas, or } \\
\text { potholes with no surface-water outflow. }\end{array}$ \\
\hline Built-up Land & $\begin{array}{l}\text { Built-up land is comprised of areas of intensive human use with much of land covered by structures. This category includes cities, towns, } \\
\text { villages, strip development along highways, transportation, power, and communication facilities, and areas such those occupied by mills, } \\
\text { shopping centers, industrial and commercial complexes, and institutions that may, in some instances, be isolated from urban areas. }\end{array}$ \\
\hline Cropland & $\begin{array}{l}\text { Cropland consists of agricultural land mainly used for cultivation of crops, and occasionally used for planting fruit trees, mulberry trees and } \\
\text { woods. It includes cultivated land, reclaimed land, and fallow fields. }\end{array}$ \\
\hline Grassland & $\begin{array}{l}\text { Grassland (rangeland) is defined as land where the natural vegetation is predominantly grasses, grass-like plants, forbs, or shrubs and where } \\
\text { natural grazing was an important influence in its pre-civilization state. }\end{array}$ \\
\hline
\end{tabular}




\section{Appendix C}

Table A3. Coverage of current institutions on the innovation arenas of different regional governance levels of Water Source Area (WSA) of Middle-Route Project (MRP).

\begin{tabular}{|c|c|c|c|c|c|}
\hline \multirow{2}{*}{\multicolumn{2}{|c|}{$\begin{array}{l}\text { LULC Based and Ecosystem Services Function } \\
\text { (ESVf) Based “Niche Ecosystem" Regions }\end{array}$}} & \multicolumn{2}{|c|}{ Beyond/Parallel to WSA of MRP } & \multirow{2}{*}{ Sub-Region of WSA of MRP } & \multirow{2}{*}{$\begin{array}{l}\text { Coverage of Current } \\
\text { Institutions }\end{array}$} \\
\hline & & Central-Government & Benefiting Area (BA) of MRP & & \\
\hline \multirow{3}{*}{$\begin{array}{l}\text { Land-use based } \\
\text { NESV }\end{array}$} & NESV of forestland & & & $\begin{array}{l}\text { - Regional economy form transformation and } \\
\text { industrial structure advancing } \\
\text { - Strict control of urban sprawl and } \\
\text { comprehensively upgrading of urban public } \\
\text { services } \\
\text { - Ad hoc measurements for forestland } \\
\text { conservation and recovery }\end{array}$ & I \\
\hline & NESV of cropland & & & $\begin{array}{l}\text { - Establishing and perfecting the agro-land } \\
\text { transfer mechanisms } \\
\text { - Controlling soil erosion and increasing land } \\
\text { utilization rate } \\
\text { - Encouraging and supporting local } \\
\text { agro-industries advancement toward } \\
\text { technology-intensive and eco-friendly }\end{array}$ & $\begin{array}{l}\text { 口 } \\
\text {. }\end{array}$ \\
\hline & $\begin{array}{l}\text { NESV of wetland and water } \\
\text { body }\end{array}$ & & & $\begin{array}{l}\text { - Regulations on point source and non-point } \\
\text { source pollution control (liquid and solid waste) } \\
\text { - Policies on facilities construction of industrial } \\
\text { and living sewage discharge and treatment } \\
\text { - Rules and regulations on industrial and living } \\
\text { sewage discharge norms and monitoring system } \\
\text { - Mechanism of capital allocation and utilization } \\
\text { of transfer payment and eco-compensation } \\
\text { scheme for advancing ecosystems of water body } \\
\text { and wetland } \\
\text { - Mechanism of wetland and water body } \\
\text { ecosystems management by regional governments } \\
\text { - Mechanisms of publicity, education and } \\
\text { participation in decision making process on } \\
\text { ecosystem management of wetland and water } \\
\text { body by local communities }\end{array}$ & $\begin{array}{l}\text {. } \\
\text { - }\end{array}$ \\
\hline
\end{tabular}


Table A3. Cont.

\begin{tabular}{|c|c|c|c|c|c|}
\hline \multirow{2}{*}{\multicolumn{2}{|c|}{$\begin{array}{l}\text { LULC Based and Ecosystem Services Function } \\
(E S V f) \text { Based "Niche Ecosystem" Regions }\end{array}$}} & \multicolumn{2}{|c|}{ Beyond/Parallel to WSA of MRP } & \multirow{2}{*}{ Sub-Region of WSA of MRP } & \multirow{2}{*}{$\begin{array}{l}\text { Coverage of Current } \\
\text { Institutions }\end{array}$} \\
\hline & & Central-Government & Benefiting Area (BA) of MRP & & \\
\hline \multirow{4}{*}{ ESF based NESV } & \multirow{2}{*}{$\begin{array}{l}\text { NESV of soil formation and } \\
\text { retention, and water supply }\end{array}$} & $\begin{array}{l}\text { - Mechanism on planning, } \\
\text { implementation and monitoring of water } \\
\text { and soil conservation in WSA of MRP }\end{array}$ & $\begin{array}{l}\text { - Mechanism on the share of } \\
\text { eco-compensation on water and soil } \\
\text { conservation among regions in BA of } \\
\text { MRP }\end{array}$ & $\begin{array}{l}\text { - Rules and regulations on strictly application of } \\
\text { supervision policies on water and soil } \\
\text { conservation }\end{array}$ & - \\
\hline & & $\begin{array}{l}\text { - Mechanism on transfer payments from } \\
\text { central government to WSA of MRP on } \\
\text { water and soil conservation } \\
\text { - Policies on advocating and promoting } \\
\text { trade market of pollution emission rights } \\
\text { in WSA of MRP } \\
\text { - Mechanism on eco-compensation } \\
\text { negotiation between BA and WSA of } \\
\text { MRP }\end{array}$ & $\begin{array}{l}\text { - Mechanism on the form of } \\
\text { eco-compensation of water and soil } \\
\text { conservation from BA of } \\
\text { MRP }\end{array}$ & & - \\
\hline & $\begin{array}{l}\text { NESV of gas regulation, } \\
\text { climate regulation, and } \\
\text { biodiversity protection }\end{array}$ & $\begin{array}{l}\text { - Planning and financial support on } \\
\text { protection of natural forest and } \\
\text { construction of water conservation forest } \\
\text { in WSA of MRP } \\
\text { - Transfer payment scheme to WSA of } \\
\text { MRP on gas regulation, climate } \\
\text { regulation, biodiversity protection from } \\
\text { the central government } \\
\text { - System on facilitating local economy } \\
\text { transformation towards low-carbon } \\
\text { emission fashion }\end{array}$ & & & - \\
\hline & $\begin{array}{l}\text { NESV of waste treatment, } \\
\text { raw material, recreation and } \\
\text { culture, and food }\end{array}$ & & & $\begin{array}{l}\text { - Rules and regulations on waste emission } \\
\text { monitoring and control } \\
\text { - Mechanism on regional pollution rights trading } \\
\text { - Principles and payment method for funds of } \\
\text { eco-compensation and transfer payment on water } \\
\text { treatment } \\
\text { - Preferential policies and financial supports on } \\
\text { industries relied on or beneficial from these ESf; } \\
\text { - Rule and regulation on control and supervision } \\
\text { of industries may harm to these ESf }\end{array}$ & - \\
\hline
\end{tabular}

- Stands for the current institution has covered this arena. 


\section{References}

1. Haigh, V.J. Environmentally Sensitive Areas. Landsc. Urban Plan. 1990, 18, 235-239. [CrossRef]

2. Cent, M.G.J. Expansion of Nature Conservation Areas: Problems with Natura 2000 Implementation in Poland? Environ. Manag. 2011, 47, 11-27.

3. Heilig, G.K. World Urbanization Prospects the 2011 Revision; UN: Washington, DC, USA, 2012.

4. Puppim de Oliveira, J.A.; Doll, C.N.H.; Kurniawan, T.A.; Geng, Y.; Kapshe, M.; Huisingh, D. Promoting win-win situations in climate change mitigation, local environmental quality and development in Asian cities through co-benefits. J. Clean. Prod. 2013, 58, 1-6. [CrossRef]

5. Buchanan, C. The Economic Impact of High Density Development and Tall Buildings in Central Business Districts. Available online: http://repository.tudelft.nl/view/MMP/uuid:0caedb65-3127-4899-a96e4ec44ef20d24/ (accessed on 4 March 2019).

6. World Bank; I.M.F. Global Monitoring Report 2013-Rural-Urban dynamics and the Millennium Development Goals; International Bank for Reconstruction and Development/The World Bank: Washington, DC, USA, 2013.

7. Cohen, B. Urbanization in developing countries: Current trends, future projections, and key challenges for sustainability. Technol. Soc. 2006, 28, 63-80. [CrossRef]

8. Wingqvist, G.Ö.; Drakenberg, O.; Slunge, D.; Sjöstedt, M.; Ekbom, A. The role of governance for improved environmental outcomes: Perspectives for developing countries and countries in transition; The Swedish Environmental Protection Agency: Stockholm, Sweden, 2012.

9. OECD. Policies for A Better Environment: Progress in Eastern Europe, Caucasus and Central Asia; OECD-publishing: Paris, France, 2007.

10. Adil, N.; Papa, M.; Taiyab, N. Global Environmental Governance: A Reform Agenda; International Institute for Sustainable Development (IISD): Manitoba, Canada, 2006.

11. OECD. Donor Support for Institutional Capacity Development in Environment: Lessons Learned; OECD-publishing: Paris, France, 1999.

12. Ostrom, E. Understanding Institutional Diversity; Princeton University Press: Princeton, NJ, USA, 2005.

13. World Bank. Sustainable Development in a Dynamic World: Transforming Institutions, Growth, and Quality of Life; World Bank: Washington, DC, USA, 2003.

14. Armitage, D.; Lo, R.D.; Plummer, R. Environmental governance and its implications for conservation practice. Conserv. Lett. 2012, 5, 245-255. [CrossRef]

15. Delmas, M.A.; Young, O.R. (Eds.) Governance for the Environment: New Perspective; Cambridge University Press: Cambridge, UK, 2009.

16. Lemos, M.C.; Agrawal, A. Environmental governance. Annu. Rev. Environ. Resour. 2006, 31, $297-325$. [CrossRef]

17. Ostrom, E. A diagnostic approach for going beyond panaceas. Proc. Natl. Acad. Sci. USA 2007, 104, 15181-15187. [CrossRef]

18. Ali-khan, F.; Mulvihill, P.R. Exploring Collaborative Environmental Governance: Perspectives on Bridging and Actor Agency. Geogr. Compass 2008, 6, 1974-1994. [CrossRef]

19. Armitage, D.R.; Plummer, R.; Berkes, F.; Arthur, R.I.; Charles, A.T.; Davidson-Hunt, I.J.; Diduck, A.P.; Doubleday, N.C.; Johnson, D.S.; Marschke, M.; et al. Adaptive co-management for social-ecological complexity. Front. Ecol. Environ. 2009, 7, 95-102. [CrossRef]

20. Armitage, D.; Marschke, M.; Plummer, R. Adaptive co-management and the paradox of learning. Glob. Environ. Chang. 2008, 18, 86-98. [CrossRef]

21. Himley, M. Geographies of Environmental Governance: The Nexus of Nature and Neoliberalism. Geogr. Compass 2008, 2, 433-451. [CrossRef]

22. Pahl-Wostl, C.; Jeffrey, P. New Approaches to Water Management: Contributions from European Research on Complexity, Learning and Uncertainty. In The Adaptiveness of IWRM: Analysing European IWRM Research; Timmerman, J.G., Pahl-Wostl, C., Möltgen, J., Eds.; IWA Publishing: London, UK, 2008.

23. Biermann, F.; Pattberg, P. Global Environmental Governance: Taking Stock, Moving Forward. Annu. Rev. Environ. Resour. 2008, 33, 277-294. [CrossRef] 
24. Liu, J.; Dietz, T.; Carpenter, S.R.; Alberti, M.; Folke, C.; Moran, E.; Pell, A.N.; Deadman, P.; Kratz, T.; Lubchenco, J.; et al. Complexity of coupled human and natural systems. Science 2007, 317, 1513-1517. [CrossRef] [PubMed]

25. Folke, C.; Hahn, T.; Olsson, P.; Norberg, J. Adaptive governance of social-ecological systems. Annu. Rev. Environ. Resour. 2005, 30, 441-473. [CrossRef]

26. Costanza, R.; Groot, R.D.; Farberll, S.; Grassot, M.; Hannon, B.; Limburg, K.; Naeem, S.; Neilltt, R.V.O.; Paruelo, J.; Raskin, R.G.; et al. value of the world' s ecosystem services and natural capital. Nature 1997, 387, 253-260. [CrossRef]

27. Torfing, J.; Peters, B.G.; Pierre, J.; Sorensen, E. Interactive Governance. Advancing the Paradigm; Oxford University Press: Oxford, UK, 2012.

28. Stojanovic, T.; Mcnae, H.M.; Tett, P.; Potts, T.W.; Reis, J.; Hance, D.; Dillingham, I. The "social" aspect of social-ecological systems: A critique of analytical frameworks and findings from a multisite study of coastal sustainability. Ecol. Soc. 2016, 21, 15. [CrossRef]

29. Asseng, S. Uncertainty in simulating wheat yields under climate change. Nat. Clim. Chang. 2013, 3, 827-832. [CrossRef]

30. Buurman, J.; Babovic, V. Adaptation pathways and real options analysis: An approach to deep uncertainty in climate change adaptation policies. Policy Soc. 2016, 35, 137-150. [CrossRef]

31. Buytaert, W.; Vuille, M.; Dewulf, A.; Urrutia, R.; Karmalkar, A. Uncertainties in climate change projections and regional downscaling in the tropical Andes: Implications for water resources management. Hydrol. Earth Syst. Sci. 2010, 14, 1247-1258. [CrossRef]

32. Mitchell, C. Designing energy policy under uncertainty. Nat. Clim. Chang. 2015, 5, 517-518. [CrossRef]

33. Koning, J.D.; Winkel, G.; Sotirov, M.; Blondet, M.; Borras, L. ScienceDirect Natura 2000 and climate change-Polarisation, uncertainty, and pragmatism in discourses on forest conservation and management in Europe. Environ. Sci. Policy 2014, 39, 129-138. [CrossRef]

34. Petr, M.; Duncan, L.G.J.B.; Anne, R.; Petr, M. New climate change information modifies frames and decisions of decision makers: An exploratory study in forest planning. Reg. Environ. Chang. 2016, 16, 1161-1170. [CrossRef]

35. Jensen, O.; Wu, X. Embracing Uncertainty in Policy-Making: The Case of the Water Sector ScienceDirect Embracing Uncertainty in Policy-Making: The Case of the Water Sector. Policy Soc. 2017, 35, 115-123. [CrossRef]

36. Sigel, K.; Klauer, B.; Pahl-wostl, C. Conceptualising uncertainty in environmental decision-making: The example of the EU water framework directive. Ecol. Econ. 2010, 69, 502-510. [CrossRef]

37. Thissen, W.; Kwakkel, J.; Mens, M. Dealing with Uncertainties in Fresh Water Supply: Experiences in the Netherlands. Water Resour. Manag. 2017, 31, 703-725. [CrossRef]

38. van den Hoek, R.E.; Brugnach, M.; Mulder, J.P.M.; Hoekstra, A.Y. Analysing the cascades of uncertainty in flood defence projects: How "not knowing enough" is related to "knowing differently". Glob. Environ. Chang. 2014, 24, 373-388. [CrossRef]

39. Capano, G.; Woo, J.J. Resilience and robustness in policy design: A critical appraisal. Policy Sci. 2017, 50, 399-426. [CrossRef]

40. Nair, S.; Howlett, M. Policy myopia as a source of policy failure: Adaptation and policy learning under deep uncertainty. Policy Politics 2017, 45, 103-118. [CrossRef]

41. UNEP (United Nations Environment Program). Environmental Education, Ethics \&Action: A Workbook to Get Started. Available online: http://www.unep.org/training/ethics_en.pdf (accessed on 5 March 2019).

42. Ryding, S.O. Environmental Management; IUS Press: Amsterdam, The Netherlands, 1998.

43. Klijn, E.H.; Koppenjan, J.F.M. Governance networks in The Public Sector; Routledge: London, UK, 2016.

44. Dewulf, A.; Biesbroek, R. Nine lives of uncertainty in decision-making: Strategies for dealing with uncertainty in environmental governance. Policy Soc. 2018, 37, 441-458. [CrossRef]

45. Jose, C.; Jabbour, C. Environmental management, climate change, CSR, and governance in clusters of small firms in developing countries: Toward an integrated analytical framework. Bus. Soc. 2015, 56, 1-22.

46. Manzano, J.J. Environmental justice, social change and pluralism. IUCN Acad. Environ. Law E J. 2012, 1, 18-29.

47. Meier, R.; Walter, F. Umweltabgaben Für Die Schweiz; Chur and Zurich: Rüegger, France, 1991; p. 31. 
48. Steger, T. Making the Case for Environmental Justice in Central \& Eastern Europe; CEU Center for Environmental Policy and Law: Budapest, Hungary, 2007; p. 9.

49. World Commission on Environment and Development (WCED). Our Common Future; Oxford University Press: Oxford, UK, 1987.

50. Taylor, D. American environmentalism: The role of race, class and gender in shaping activism, 1820-1995. Race Gend. Class 1997, 5, 16-62.

51. Novotny, P. Where We Live, Work and Play: The Environmental Justice Movement and the Struggle for a New Environmentalism; Praeger: Westport, CT, USA, 2000.

52. Brulle, R.J.; Pellow, D.N. Environmental justice: Human health and environmental inequalities. Ann. Rev. Public Health 2005, 27, 1-22. [CrossRef] [PubMed]

53. Downey, L.; Van Willigen, M. Environmental stressors: The mental health impacts of living near industrial activity. J. Health Soc. Behav. 2005, 46, 289-305. [CrossRef] [PubMed]

54. Evans, G.W.; Kantrowitz, E. Socioeconomic status and health: The potential role of environmental risk exposure. Ann. Rev. Public Health 2002, 23, 303-331. [CrossRef] [PubMed]

55. Clapp, J. Toxic Exports: The Transfer of Hazardous Wastes from Rich to Poor Countries; Cornell University Press: Ithaca, NY, USA, 2001.

56. Roberts, J.T.; Parks, B.C. A Climate of Injustice: Global Inequality, North-South Politics, and Climate Policy; The MIT Press: Cambridge, MA, USA, 2007.

57. Smith, T.; Sonnenfeld, D.A.; Pellow, D.N. Challenging the Chip: Labor Rights and Environmental Justice in the Global Electronics Industry; Temple University Press: Philadelphia, PA, USA, 2006.

58. Washington, S.H.; Rosier, P.C.; Goodall, H. Echoes from the Poisoned Well: Global Memories of Environmental Injustice; Lexington Books: New York, NY, USA, 2006.

59. Bullard, R.D. The Quest for Environmental Justice: Human Rights and the Politics of Pollution; Sierra Club Books: San Francisco, CA, USA, 2005.

60. Pellow, D.N.; Brulle, R.J. Power, Justice, and the Environment: A Critical Appraisal of the Environmental Justice Movement; The MIT Press: Cambridge, MA, USA, 2005.

61. Roberts, J.T.; Toffolon-Weiss, M.M. Chronicles from the Environmental Justice Frontline; Cambridge University Press: Cambridge, UK, 2001.

62. Mohai, P.; Pellow, D.; Roberts, J.T. Environmental justice. Ann. Rev. Environ. Resour. 2009, 34, 405-430. [CrossRef]

63. Held, V. The Ethics of Care: Personal, Political, Global; University of Oxford Press: Oxford, UK, 2006.

64. Dietz, T.; Ostrom, E.; Stern, P.C. The struggle to govern the commons. Science 2003, 302, 1907-1912. [CrossRef]

65. Armitage, D.R.; Berkes, F.; Doubleday, N. Introduction: Moving beyond co-management. In Adaptive Co-Management: Collaboration, Learning, and Multi-Level Governance; Armitage, D.R., Berkes, F., Doubleday, N., Eds.; University of British Columbia Press: Vancouver, BC, Canada, 2007; pp. 1-15.

66. Plummer, R.; Armitage, D. A resilience-based framework for evaluating adaptive co-management: Linking ecology, economics and society in a complex world. Ecol. Econ. 2006, 61, 62-74. [CrossRef]

67. Gunderson, L.H.; Holling, C.S. (Eds.) Panarchy: Understanding Transformations in Human and Natural Systems; Island Press: Washington, DC, USA, 2002.

68. Brunner, R.D.; Steelman, T.D.; Coe-Juell, L.; Cromley, C.M.; Edwards, C.M.; Tucker, D.W. Adaptive Governance: Integrating Science Policy and Decision Making; Columbia University Press: New York, NY, USA, 2006.

69. Olsson, P.; Gunderson, L.H.; Carpenter, S.R.; Ryan, P.; Lebel, L.; Folke, C.; Holling, C.S. Shooting the rapids: Navigating transitions to adaptive governance of social-ecological systems. Ecol. Soc. 2006, 11, 18. [CrossRef]

70. Allen, C.R.; Fontaine, J.J.; Pope, K.L.; Garmestani, A.S. Adaptive management for a turbulent future. J. Environ. Manag. 2011, 92, 1339-1345. [CrossRef]

71. Westgate, M.J.; Likens, G.E.; Lindenmayer, D.B. Adaptive management of biological systems: A review. Biol. Conserv. 2013, 158, 128-139. [CrossRef]

72. Huitema, D.; Mostert, E.; Moellenkamp, S.; Pahl-wostl, C. Adaptive Water Governance: Assessing the Institutional Prescriptions of Adaptive (Co-) Management from a Governance Perspective and Defining a Research Agenda Adaptive Water Governance: Assessing the Institutional Prescriptions of. Ecol. Soc. 2009, 14, 26. [CrossRef]

73. North, D.C. Institutions, Institutional Change and Economic Performance; Cambridge University Press: Cambridge, UK, 1990. 
74. Princen, T.M. Finger Environmental NGOs in World Politics: Linking the Local and the Global; Routledge: London, UK, 1994.

75. Lipschutz, R.D. Global Civil Society and Global Environmental Governance: The Politics of Nature from Place to Planet; State University of New York Press: Albany, NY, USA, 1996.

76. Humphreys, D. Regime theory and Non-Governmental Organizations: The case of forest conservation. In NGOs and Environmental Policies: Asia and Africa; Potter, D., Ed.; Frank Cass: London, UK, 1996.

77. Raustiala, K. The "participatory revolution" in international environmental law. Harvard Environ. Law Rev. 1997, 21, 537-586.

78. Treib, O.; Bähr, H.; Falkner, G. Modes of governance: A note towards conceptual clarification. J. Eur. Public Policy 2005, 14, 1-20. [CrossRef]

79. Scott, R.W. Institutional and Organization, 2nd ed.; Sage Publication: Thousand Oaks, CA, USA, 2001.

80. Wilder, M.; Lankao, P.R. Paradoxes of Decentralization: Water Reform and Social Implications in Mexico. World Dev. 2006, 34, 1977-1995. [CrossRef]

81. Swallow, B.M.; Garrity, D.P.; van Noordwijk, M. The effects of scales, flows and filters on property rights and collective action in watershed management. Water Policy 2001, 3, 457-474. [CrossRef]

82. Tolbert, P.; Zucker, L.G. The Institutionalization of Institutional Theory; Clegg, S.R., Hardy, C., Nord, W.R., Eds.; The Handbook of Organization Studies; Sage: London, UK, 1996; pp. 175-190.

83. Feenberg, A. Modernity Theory and Technology Studies: Reflections on Bridging the Gap; Misa, T., Brey, P., Feenberg, A., Eds.; Modernity and Technology; MIT Press: Boston, MA, USA, 2003.

84. Radder, H. Normative reflexions on constructivist approaches to science and technology. Soc. Stud. Sci. 1992, 22, 141-173. [CrossRef]

85. Winner, L. Social constructivism: Opening the black box and finding it empty. Sci. Cult. 1993, 3, 427-452. [CrossRef]

86. Law, J. Notes on the theory of the actor-network: Ordering, strategy, and heterogeneity. Syst. Pract. 1992, 5, 379-393. [CrossRef]

87. Dankert, R.; Latour, B.; Callon, M.; Law, J. Actor-Network theory. Int. Encycl. Hous. Home 2012, 19, 46-50.

88. Lawrence, T.B.; Suddaby, R. Institutions and Institutional Work. In Sage Handbook of Organization Studies; Stewart, R., Clegg, C.H., Lawrence, T.B., Nord, W.R., Eds.; Sage: London, UK, 2006; pp. 215-254.

89. Brugnach, M.; Dewulf, A.; Henriksen, H.J.; van der Keur, P. More is not always better: Coping with ambiguity in natural resources management. J. Environ. Manag. 2011, 92, 78-84. [CrossRef] [PubMed]

90. Dewulf, A.; Craps, M.; Bouwen, R.; Taillieu, T. Integrated management of natural resources: Dealing with ambiguous issues, multiple actors and diverging frames. Water Sci. Technol. 2018, 52, 115-124. [CrossRef]

91. Koppenjan, J.F.M.; Klijn, E.H. Managing Uncertainties in Networks. A Network Approach to Problem Solving and Decision Making; Routledge: New York, NY, USA, 2004.

92. Kwakkel, J.H.; Walker, W.E.; Marchau, V.A.W.J. Classifying and communicating uncertainties in model-based policy analysis. Int. J. Technol. Policy Manag. 2010, 10, 299. [CrossRef]

93. Taylor, P.; Walker, W.E.; Harremoës, P.; Rotmans, J.; van der Sluijs, J.P.; van Asselt, M.B.A. Defining Uncertainty: A Conceptual Basis for Uncertainty Management in Model-Based Decision Support. Integr. Assess. 2010, 4, 37-41.

94. Roberts, N. Wicked problems and networks approaches to resolution. Public Manag. Rev. 2000, 1, 1-19.

95. van Bueren, E.M.; Klijn, E. Dealing with Wicked Problems in Networks: Analyzing an Environmental Debate from a Network Perspective. J. Public Adm. Res. Theory 2003, 13, 193-212. [CrossRef]

96. Gerrits, L.; Verweij, S. When governance networks become the agenda. Public Administration Review. 2017, 77, 144-146. [CrossRef]

97. Ministry of Water Resources of the People's Republic of China Bulletin of China's Water Resources in 2010. Available online: http://www.mwr.gov.cn/zwzc/hygb/szygb/qgszygb/201204/t20120426_319624.html (accessed on 5 March 2019). (In Chinese)

98. Kong, X. China must protect high-quality arable land. Nature 2014, 506, 7. [CrossRef]

99. Chang, T.C. (Ed.) Sanmenxia Statistical Yearbook; China Statistics Press: Beijing, China, 2011. (In Chinese)

100. Li, Z.T.; Xia, Z.K. (Eds.) Hubei Statistical Yearbook; China Statistics Press: Beijing, China, 2011. (In Chinese)

101. Zhang, S.J. (Ed.) Luoyang Statistical Yearbook; China Statistical Press: Beijing, China, 2011. (In Chinese)

102. Zhang, X.G. (Ed.) Shaanxi Statistical Yearbook; China Statistical Press: Beijing, China, 2011. (In Chinese)

103. Du, X.P.; Dong, S.R. (Eds.) Tianjin Statistical Yearbook; China Statistical Press: Beijing, China, 2011. (In Chinese) 
104. Yu, X.Q. (Ed.) Beijing Statistical Yearbook; China Statistical Press: Beijing, China, 2011. (In Chinese)

105. Foody, G.M.; Mathur, A. Toward intelligent training of supervised image classifications: Directing training data acquisition for SVM classification. Remote Sens. Environ. 2004, 93, 107-117. [CrossRef]

106. Xie, G.D.; Lu, C.X.; Leng, Y.F.; Zheng, D.; Li, S.C. Ecological assets valuation of the Tibetan Plateau. J. Nat. Resour. 2003, 18, 189-196. (In Chinese)

107. Wang, Y.P. Study on the issue of eco-compensation of water sources area of Middle Route Project of South-North Water Diversion Project-based on the angle of ecosystem services value. J. Nanyang Inst. Technol. 2011, 3, 67-71. (In Chinese)

108. Chien, S. Local responses to globalization in China: A territorial restructuring process. Pacific Econ. Rev. 2008, 13, 492-517. [CrossRef]

109. Loorbach, D. Transition management for sustainable development: A prescriptive, complexity-based governance framework. Governance 2010, 23, 161-183. [CrossRef]

110. Vatn, A. Institutions and the Environment; Edward Elgar Publishing, Inc: Northhampton, UK, 2005.

111. Swedberg, R. Book Reviews: Douglass C. North: Institutions, Insti tutional Change and Economic Performance. Cambridge: Cambridge University Press, 1990. Acta Sociol. 1993, 36, 298-300. [CrossRef]

112. March, J.; Friedbergy, E.; Arellano, D. Institutions and organizations: Differences and linkages from organization theory. Gestión y Política Pública. 2011, 20, 235-246.

113. Atran, S. Religion's evolutionary landscape: Counterintuition, commitment, compassion, communion. Behav. Brain Sci. 2004, 27, 713-770. [CrossRef] [PubMed]

114. Barrett, J.L. Exploring the natural foundations of religion. Trends Cogn. Sci. 2000, 4, 29-34. [CrossRef]

115. Boyer, P. Religious thought and behaviour as by-products of brain function. Trends Cogn. Sci. 2003, 7, 119-124. [CrossRef]

116. Dedeurwaerdere, $\mathrm{T}$. The contribution of network governance to sustainable development. Les séminaires $l^{\prime} I d d r i, n^{\circ} 13$, Iddri 2005, 33, 1-15.

117. Stoker, G.; Stoker, G. Governance as theory: Five propositions. Int. Soc. Sci. J. 1998, 50, 17-28. [CrossRef]

118. Sonnenfeld, D.A. Globalization and the transformation of environmental governance: An introduction. Am. Behav. Sci. 2002, 45, 1318-1339. [CrossRef]

119. Kaika, M. The Water Framework Directive: A new directive for a changing social, political and economic European framework. Eur. Plan. Stud. 2010, 11, 299-316. [CrossRef]

120. Pahl-Wostl, C.; Gupta, J.; Petry, D. Governance and the global water system: A theoretical exploration. Glob. Gov. 2008, 14, 419-435. [CrossRef]

121. Bryant, R.L.; Wilson, G.A. Rethinking environmental management. Prog. Hum. Geogr. 1998, 22, $321-343$. [CrossRef]

122. Plummer, R.; Armitage, D. Crossing Boundaries, Crossing Scales: The Evolution of Environment and Resource. Geogr. Compass 2007, 1, 834-849. [CrossRef]

123. Pahl-Wostl, C. The implications of complexity for integrated resources management. Environmental Modelling $\mathcal{E}$ Software. 2007, 22, 561-569.

124. Armitage, D.; International, S.; January, N.; Armitage, D. Governance and the commons in a multi-level world. Int. J. Commons 2008, 2, 7-32. [CrossRef]

125. Ansell, C.; Gash, A. Collaborative Governance in Theory and Practice. J. Public Adm. Res. Theory 2018, 18, 543-571. [CrossRef]

126. Denis, J.L.; Langley, A.; Rouleau, L. Studying Strategizing in Pluralistic Contexts: A Methodological Agenda; Working Paper; Universite de Montreal and HEC: Montreal, QC, Canada, 2004.

127. Biermann, F.; Betsill, M.M.; Gupta, J.; Kanie, N.; Lebel, L.; Liverman, D.; Schroeder, H.; Siebenhüner, B.; Conca, K.; da Costa Ferreira, L.; et al. Earth System Governance: People, Places and the Planet. Science and Implementation Plan of the Earth System Governance Project; International Human Dimensions Programme on Global Environmental Change: Bonn, Germany, 2009.

128. World Resources 2002-2004: Decisions for the Earth-Balance, Voice, and Power; World Resources Institute: Washington, DC, USA, 2004.

129. Christensen, N.L.; Bartuska, A.M.; Brown, J.H.; Carpenter, S.; Antonio, C.D.; Francis, R.; Franklin, J.F.; Macmahon, J.A.; Noss, R.F.; Parsons, J.; et al. The report of the Ecological Society of America committee on the scientific basis for ecosystem management. Ecol. Appl. 1996, 6, 665-691. [CrossRef] 
130. Kemp, R.; Martens, P. Sustainable development: How to manage something that is subjective and never can be achieved? Sustainable development: How to manage something that is subjective and never can be achieved? Sustain. Sci. Pract. Policy 2007, 3, 5-14.

131. OECD. The Social Dimension of Environmental Policy (Policy Brief); Organisation for Economic Co-operation and Development: Paris, France, 2006.

132. Environment Agency. Addressing Environmental Inequalities: Flood Risk, Waste Management and River Water Quality in Wales; Science Report SC020061/SR5; The Environment Agency: Bristol, UK, 2007.

133. Pye, S.; Skinner, I.; Meyer-Ohlendorf, N.; Leipprand, A.; Lucas, K.; Salmons, R. Addressing the Social Dimensions of Environmental Policy -A Study on the Linkages Between Environmental and Social Sustainability in Europe; European Commission Directorate General "Employment, Social Affairs and Equal Opportunities". 2008. Available online: http://ec.europa.eu/social/BlobServlet?docId=1672\&langId=en (accessed on 15 August 2019).

134. Emelianoff, C. Connaître ou Reconnaître Les Inégalités Environnementales? ESO 2006, 25, 35-43.

(C) 2019 by the authors. Licensee MDPI, Basel, Switzerland. This article is an open access article distributed under the terms and conditions of the Creative Commons Attribution (CC BY) license (http://creativecommons.org/licenses/by/4.0/). 